\title{
El Conjunto Rupestre de Bacinete, Sierra del Niño, Los Barrios, Cádiz. Primeros resultados
}

\section{The Rock shelters of Bacinete, Sierra del Niño, Los Barrios, Cadiz. The first results}

\author{
Mónica Solís Delgado*
}

\section{RESUMEN ABSTRACT}

El conjunto de abrigos decorados con pinturas postpaleolíticas que componen

Bacinete, pertenecientes al término municipal de Los Barrios, constituye una de las estaciones más importantes de toda la provincia de Cádiz. Por temática y estilo, se sitúa en un contexto postpaleolítico de primeros productores, $y$ se adscribe estilísticamente al horizonte esquemático.

\section{PALABRAS CLAVE}

Bacinete, Laguna de la Janda, arte postpaleolítico, arte esquematico, pinturas rupestres.
The shelters decorated with postpalaeolithic paintings that are found in the village area of Los Barrios and that comprise Bacinete, it is a important station of this kind in the whole of Cádiz province. By its subject and style it is framed in a postpalaeolithic context of first producers and stylistically speaking it ascribes itself to the schematic horizon.

\section{KEY WORDS}

Bacinete, Laguna de la Janda, postpalaeolithic art, schematic art, rock paintings.

* Departamento de Prehistoria y Arqueología, UNED. 


\section{INTRODUCCIÓN}

El Conjunto rupestre de Bacinete es un enclave de gran importancia en cuanto a manifestaciones rupestres prehistóricas se refiere, no en vano en $1929 \mathrm{H}$. Breuil y M.C. Burkitt en su obra Rock paintings of Southern Andalusia. A description of a Neolithic and Copper Age art group, llegan a calificarlo como el más importante de toda la provincia de Cádiz después de la Cueva del Tajo de la Figuras.

A pesar de ello, el lugar desde entonces no ha sido objeto de un estudio exhaustivo en el que se aplicasen las nuevas técnicas que se han venido incorporando al estudio del arte prehistórico. Los únicos acercamientos a esta estación desde entonces han sido breves y en algunos casos más divulgativos que científicos.

Entre 1988 y 1993 se llevó a cabo el proyecto general de investigación arqueológica Las manifestaciones rupestres prehistóricas de la zona gaditana, dirigido por Martí Mas Cornellà, con la autorización y subvención de la Dirección General de Bienes Culturales de la Junta de Andalucía. En este proyecto se abordó el estudio de las manifestaciones rupestres prehistóricas de las sierras que bordean la antigua Laguna de La Janda, culminando con la publicación de una memoria científica. En esta obra se someten a estudio, sobre todo, las manifestaciones rupestres situadas en Sierra Momia, pero en el proyecto se abordó el trabajo de campo en Sierra del Niño, que quedó inédito a la espera del trabajo de gabinete. Por ello, el presente artículo es un resumen de los primeros resultados obtenidos del trabajo de gabinete que actualmente se viene realizando de este material que había quedado inédito, donado amablemente por el Dr. Martí Mas Cornellà y que se plasmaron en el trabajo de investigación de tercer ciclo El Conjunto rupestre de Bacinete (Sierra del Niño, Los Barrios, Cádiz)².

Bacinete se encuentra en la anteriormente mencionada Sierra del Niño, uno de los accidentes orográficos que rodean la antigua Laguna de la Janda, antiguo humedal desecado a mediados del siglo XX. Resulta importante el estudio de las representaciones plásticas de Sierra del Niño para una aproximación a la Prehistoria de la zona. Como se planteó en el trabajo precedente, en el que se abordó el estudio de las cavidades situadas en Sierra Momia, la ocupación humana tuvo un fuerte reflejo cultural plasmado en la gran proliferación de manifestaciones rupestres, por ello resulta de gran interés la continuación del estudio de la zona, añadiendo el análisis de las representaciones artísticas de Sierra del Niño.

Por otra parte, el Conjunto rupestre de Bacinete por sí mismo cuenta con pinturas rupestres de inestimable valor, que merecen un estudio detallado y su puesta en valor.

2 Solís Delgado, Mónica: El Conjunto rupestre de Bacinete (Sierra del Niño, Los Barrios, Cádiz). UNED, diciembre de 2005 (Trabajo de investigación de tercer ciclo, nota final: Sobresaliente por unanimidad). 
Bacinete constituye, sin duda, un enclave de importancia notable dentro del arte postpaleolítico, más concretamente dentro del fenómeno esquemático, algunas de sus imágenes han sido recogidas en publicaciones como paradigmas de dicho fenómeno, sirvan de ejemplo los antropomorfos de tendencia naturalista que portan hachas, según $\mathrm{H}$. Breuil, motivos repetidamente reproducidos.

El trabajo se ha abordado desde la observación y estudio exhaustivo del material fotográfico y gráfico obtenido anteriormente, a partir del cual se han realizado reproducciones, estadísticas, se ha puesto en relación con estudios precedentes y estaciones cercanas o análogas, con la intención de aportar datos alcanzados desde un método científico lo más objetivo posible, tratando de huir de cuestiones epistemológicas e ideas preconcebidas.

En abril de 2005 se realizó una contrastación in situ, para comprobar los datos procesados. Se procedió a la toma de algunas fotografías. Con este material se ha podido abordar una estimación del impacto de las intervenciones humanas en el lugar desde la finalización de los trabajos de campo en que está basado este estudio hasta hoy.

\section{METODOLOGÍA}

Como se ha destacado, el material inédito obtenido a través del trabajo de campo que se llevó a cabo en el Conjunto rupestre de Bacinete, estaba inserto dentro de un proyecto que incluía las sierras que bordean la antigua Laguna de la Janda. El proyecto se inicia en 1988, pero las actuaciones en las cavidades que nos ocupan se desarrollaron durante los años 1989, 1990, 1991 y 1992.

La metodología del trabajo de campo consistió en la localización de los lugares, realización de las topografías de cada estación*, toma de fotografías de los paneles, escenas y figuras, así como la observación de otras evidencias arqueológicas o etnográficas destacables.

\subsection{Localización cartográfica}

En un primer momento se procedió a la localización cartográfica de los abrigos en mapas de diferentes escalas. A partir del Mapa Militar Digital de España del Ministerio de Defensa ${ }^{3}$ se consiguió una primera aproximación al entorno de la antigua Laguna de la Janda. Para ello se utilizó su aproximación máxima 1:250.000, así se consiguieron diferentes planimetrías de la zona, mapa en tres dimensiones, de curvas de nivel, planimetría axial, toponímico y combinaciones de los anteriores.

* Agradecemos la colaboración de Joan Pallarés-Personat.

3 Ministerio de Defensa. Ejercito de Tierra. 1997. 
El siguiente paso consistió en un acercamiento más concreto al entorno de Sierra del Niño, para ello se requirieron escalas menores que permitieran observar más detalladamente el territorio, en este caso se recurrió al mapa 1:50.000 de la Cartografía Militar de España ${ }^{4}$ y al mapa Topográfico Nacional de España 1:25.000, del Instituto Geográfico Nacional ${ }^{5}$.

El proceso de análisis cartográfico se completó con la realización de un mapa específico del fragmento de territorio donde se localizan las cavidades a escala $1: 25.000^{6}$, realizado en tinta china, mejorado con Adobe Photshop 7.0 y Adobe ImageReader 7.0, para la plasmación de los signos convencionales específicos.

\subsection{Topografías}

La realización de las topografías ha consistido en el dibujo de la planta y perfil de los bloques prismáticos que sirven de soporte a las representaciones. Para ello contamos con los croquis topográficos realizados a lápiz sobre papel milimetrado por miembros del equipo que llevó a cabo el trabajo de campo.

Se realizaron dibujos en papel vegetal a tinta china, utilizando estilográficos con diferentes grosores $(0.2,0.4$ y 0.8$)$ y distintos tipos de trazos para distinguir así las diferentes líneas topográficas, suelo, techo y fondo. Una vez escaneadas estas imágenes se mejoraron con los programas Adobe Photoshop 7.0 y Adobe ImageReader 7.0, donde además se diseñaron los signos convencionales propios de las topografías y perfiles.

\subsection{Documentación del arte rupestre}

La documentación de las manifestaciones artísticas se abordó a partir del completo archivo fotográfico compilado durante los trabajos de campo del proyecto de investigación arqueológica Las manifestaciones rupestres prehistóricas de la zona gaditana, en el que se realizó la documentación integra fotográfica del arte rupestre, entendiendo como tal la reproducción de cada uno de los motivos o escenas, y la toma de fotografías encaminadas a la localización exacta de la totalidad de las figuras.

Dado que las técnicas fotográficas utilizadas en el trabajo de campo son de principios de los 90 , es obvio decir que no se trata de material digital, dado que dichas técnicas no estaban aún desarrolladas. Debido a ello el primer paso fue el

4 Tahivilla. Hoja n. ${ }^{\circ}$ 13-47 (1074). Cartografía Militar de España. Servicio Geográfico del Ejército. Madrid, 1990.

5 Tahivilla. 1074-IV Zanona (26-94). Instituto Geográfico Nacional. Ministerio de Fomento. Madrid, 1998.

6 Mapa basado en el mapa 1:25.000. 1074-IV Tahivilla. Zanona (26-94). 
proceso de escaneado y digitalización de este material, ésta se hizo con una resolución optima, $18 \mathrm{Mb}$ Tiff para cada imagen, se trató así de transformar un material analógico de alta calidad a un material digital de calidad semejante. La intención era poder aplicar a una información recogida a principios de los 90 las técnicas de laboratorio actuales.

Una vez digitalizado el material se ha procedido a la reconstrucción digital de los paneles completos y de cada motivo individual.

La realización de estas reconstrucciones globales e individuales se ha conseguido mediante el programa Adobe Photoshop 7.0. El tratamiento de cada fotografía ha sido distinto dependiendo de las condiciones de la fotografía o del estado de conservación del motivo, el objetivo ha sido la obtención de la máxima visibilidad del motivo pictórico. Para ello, se han corregido los niveles de los canales de color, se ha alterado el color, el contraste, el tono y la saturación en diferentes grados, en función de cada foto con el objetivo de obtener mayor distancia cromática entre los motivos pintados y el soporte a través de la desaturación del soporte y la saturación del pigmento o al incremento de contraste entre colores.

A partir de la mejora de la definición del motivo pintado, se ha procedido a la selección de áreas de color identificadas como pintura, por medio de diversas herramientas, principalmente se ha utilizado la selección de píxeles variando los niveles de tolerancia y la continuidad o discontinuidad de los mismos según las condiciones de la fotografía o del motivo. Se obtiene así un fichero vectorial a escala que se exporta a Adobe Illustrator. A la selección obtenida identificada como pigmento se le somete a diferentes filtros para mejorar la visualización de los trazos que componen el motivo pictórico, filtro punteado casi siempre, y en algunos casos se le somete también a bordes añadidos.

Con el borrador y manejando la lupa para acercar y alejar la imagen se procede a la limpieza de píxeles residuales que no corresponden a pintura, se obtiene así la reproducción digital que se guarda en formato PSD.

A través de este sistema digital electrónico se consiguen las reproducciones de las representaciones pictóricas sin necesidad de entrar en contacto directo con las propias pinturas, de este modo es posible un estudio exhaustivo sin necesidad de dañar las manifestaciones en modo alguno como cabría la posibilidad en el calco directo dada la fragilidad que caracteriza a las manifestaciones prehistóricas. Por otra parte el método resulta más exhaustivo y científico, ya que la posibilidad de alteración en el material fotográfico de factores como el contraste, la saturación, etc., permite la visualización de zonas de pigmentación que su localización resultaría imposible mediante el tratamiento convencional directo. La selección de áreas esta basada en la gama de color, por lo que las reproducciones no están determinadas por ideas o interpretaciones preconcebidas, sino que la identificación y la interpretación vendrán determinadas por la reproducción obtenida y no al contrario. 
Una vez obtenidas las reproducciones digitales, se ha procedido a la numeración de los motivos. Para ello a cada motivo se le ha asignado una signatura o localizador, en el que se consigna un número curren para contabilizar todos los motivos del conjunto rupestre, el abrigo al que pertenece, un número de panel y un numero curren dentro del abrigo. Por ejemplo; 001.B01.P01.001 sería la figura 1 del conjunto rupestre de Bacinete, que estaría en el abrigo de Bacinete I, en el panel I del mismo, y sería la figura primera del panel. El número curren va en relación con la posición que ocupa la figura dentro del abrigo, va de izquierda a derecha y de arriba abajo del panel.

Se ha realizado una descripción detallada de cada figura, en la que se ha incluido, además, la clasificación, el estado de conservación y las posibles asociaciones. Paralelamente se ha codificado en una base de datos ACCES y en una hoja de cálculo EXCEL la información de cada motivo con su correspondiente localizador. Mediante filtros y consultas se han obtenido datos estadísticos. Así se han elaborado estadísticas por abrigo, tratando cada cavidad de modo individual y estadísticas globales.

De este tratamiento de la información se han podido extraer datos acerca del estilo, porcentajes tipológicos, tipos de asociaciones, en definitiva una información exhaustiva, a partir de la cual se ha reflexionado para extraer posibles conclusiones e interpretaciones, identificaciones, fases de ejecución, estado de conservación, etc.

\section{APROXIMACIÓN A LOS ASPECTOS FÍSICOS Y GEOLÓGICOS}

Dentro de las unidades alóctonas del Campo de Gibraltar, área incluida en las Cordilleras Béticas, se halla el conjunto rupestre de Bacinete, enclavado en la llamada Sierra del Niño, que junto a otras como Sierra Momia, Sierra Blanquilla o Sierra Sequilla... componen los accidentes orográficos que rodean la depresión tectónica de la antigua Laguna de la Janda. El Campo de Gibraltar se configuró como un conjunto de mantos de corrimiento apilados, constituidos por materiales cretácicos y paleógenos, en los que destacan los sedimentos tipo Flysch. Se originan así, plegamientos con direcciones Noreste-Sureste, que se continúan en el Rif Marroquí. Las facies Flychs consisten en diversas formaciones arcillosas y areniscosas que estarían comprendidas entre el Cretácico y el Mioceno Inferior, es decir materiales estratificados que posteriormente serán levantados por la orogenia Alpina.

La Sierra del Niño contiene numerosas cavidades y abrigos rocosos de pequeño tamaño, originados por corrosión y erosión eólica, junto con superficies corroídas en extensión, dando lugar en conjunto a una morfología en tafonis de areniscas silíceas ${ }^{7}$. El llamado Gran Abrigo de Bacinete es, sin duda, un claro

7 Mas Cornellá, Jordá Pardo, Cambra Sánchez, Mas Riera y Lombarte Carrera, 1994. 


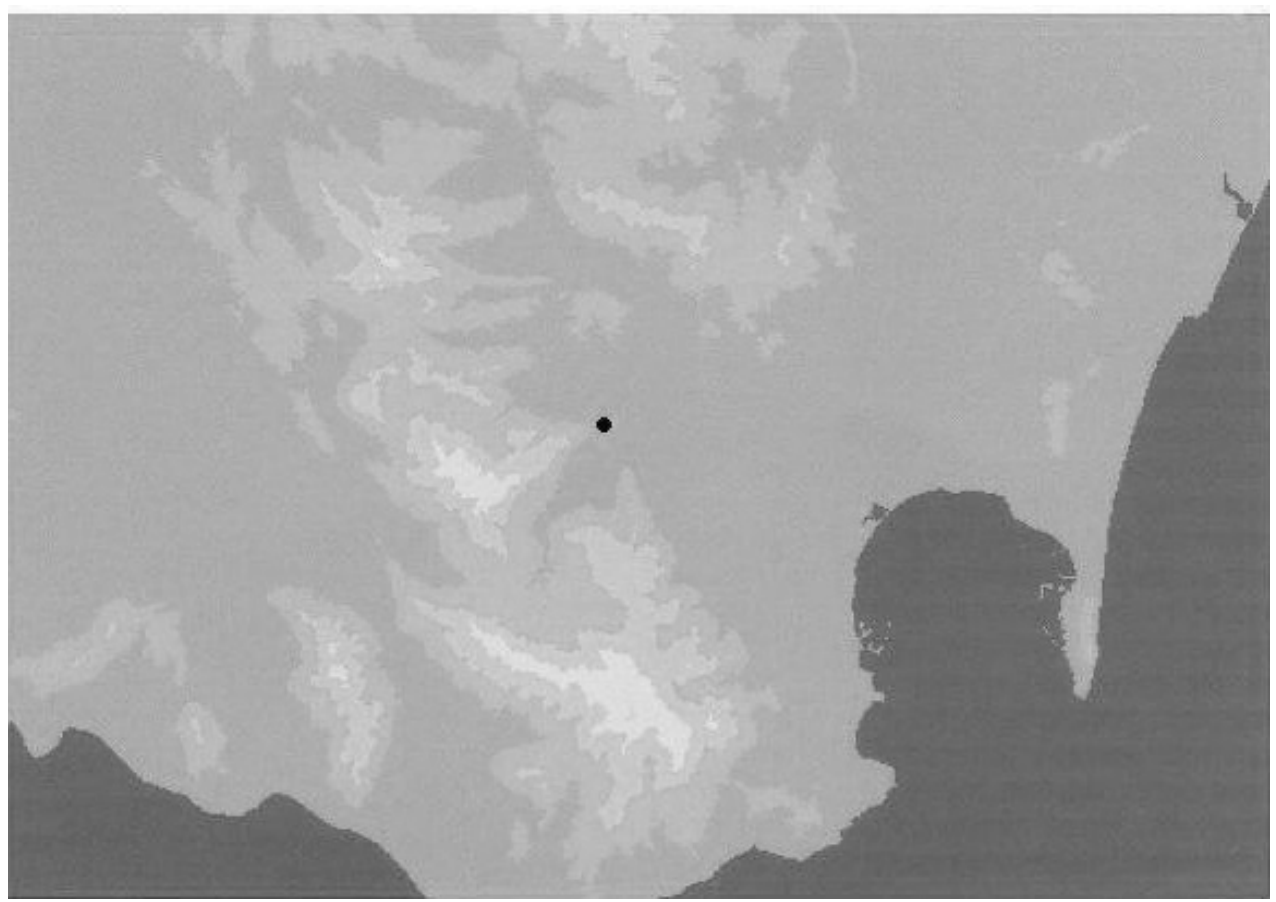

Fig. 1. Localización del Conjunto rupestre de Bacinete.

ejemplo de formación en relieve producto de la erosión eólica, la consecuencia de ello será la formación de superficies cóncavas, ideales para ser utilizadas como soporte para las representaciones pictóricas.

Bacinete se compone de una serie de estos abrigos rocosos que albergan manifestaciones pictóricas prehistóricas.

El conjunto rupestre de Bacinete se halla adscrito al término municipal de Los Barrios, en la ladera suroccidental del Cerro Peruétano, cercano a la confluencia del río Ojén con el río Cañas, dentro del Parque Natural de los Alcornocales.

Está formado por abrigos de areniscas del Aljibe, que en esta zona son muy numerosos, de ellos, sólo van a presentar representaciones Bacinete VIII o Gran Abrigo, que en su cara opuesta, va a ser denominado Bacinete IV y seis abrigos más, Bacinete I, II, III, V, VI ${ }^{8} \mathrm{y}$ VII ${ }^{9}$. Bacinte V, está constituido por dos bloques que forman una pequeña cueva. Las diferentes cavidades se sitúan en torno a una altura que oscila entre los 150 y los 220 metros.

8 Denominación de los lugares debida a Breuil y Burkitt, 1929.

9 Mas Cornellá, 1990. 
Aunque desde la zona se puede dominar una amplia panorámica del paisaje del actual Parque Natural de los Alcornocales, lo cierto es que el conjunto de estaciones se encuentra en una pequeña hondonada semioculto por las formaciones boscosas propias un piso bioclimático Mesomediterráneo, siendo difícil su localización desde el sur, sin embargo ésta es más fácil desde el este. Se trata de un lugar muy conocido por la belleza del paisaje y el conocimiento de su existencia es generalizado en la zona, de ahí las graves agresiones antrópicas que han afectado seriamente a las representaciones.

Las manifestaciones rupestres, a excepción de Bacinete $\mathrm{V}$, se localizan en las paredes cóncavas de los bloques erosionados, los abrigos son de diferentes dimensiones, destacan los más de diecisiete metros de longitud del bloque que contiene en sus dos extremos Bacinete IV y el Gran Abrigo o Bacinete VIII. Por el contrario las profundidades son similares en las superficies cóncavas, lugar donde se encuentran las representaciones pictóricas prehistóricas, oscilando entre los tres metros y medio y un metro en las zonas donde la línea de techo está más próxima a la de fondo del abrigo.

Es mayoritaria la tendencia hacia la orientación sur, este o sudeste de las representaciones pictóricas, salvo en el caso de Bacinete $\mathrm{V}$ y IV con orientación norte.

\section{DOCUMENTACIÓN DE LAS MANIFESTACIONES ARTÍSTICAS}

\subsection{Bacinete I}

Localización: (Coordenadas UTM) X: 270.50, Y: 4009.25. Mapa Topográfico Nacional de España. Escala 1:25.000. Zanona. 1074-IV. Instituto Geográfico Nacional.

Morfología: Abrigo rocoso $(2.4$ (altura) $\times 8.1$ (anchura) $\times 1.9 \mathrm{~m}$ (profundidad)) 


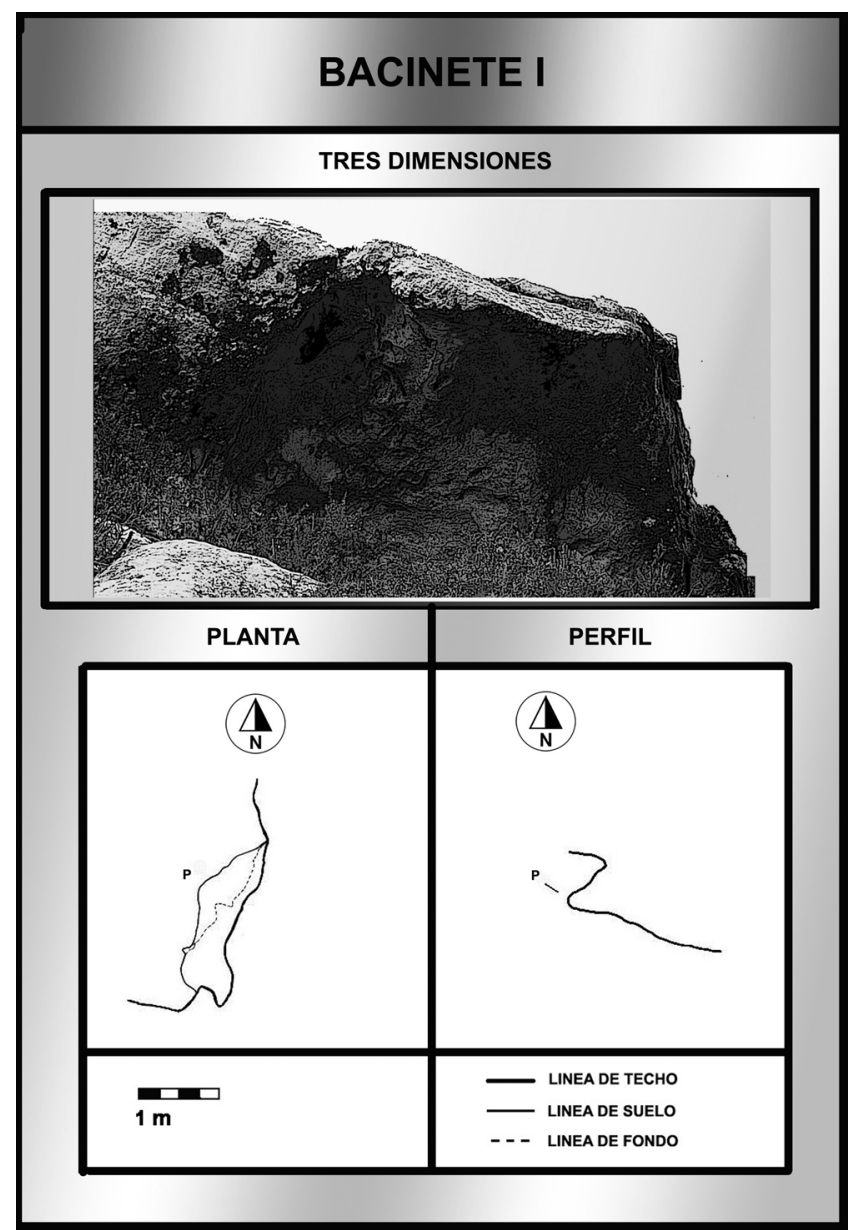

Fig. 2. Bacinete I. Planta y perfil.

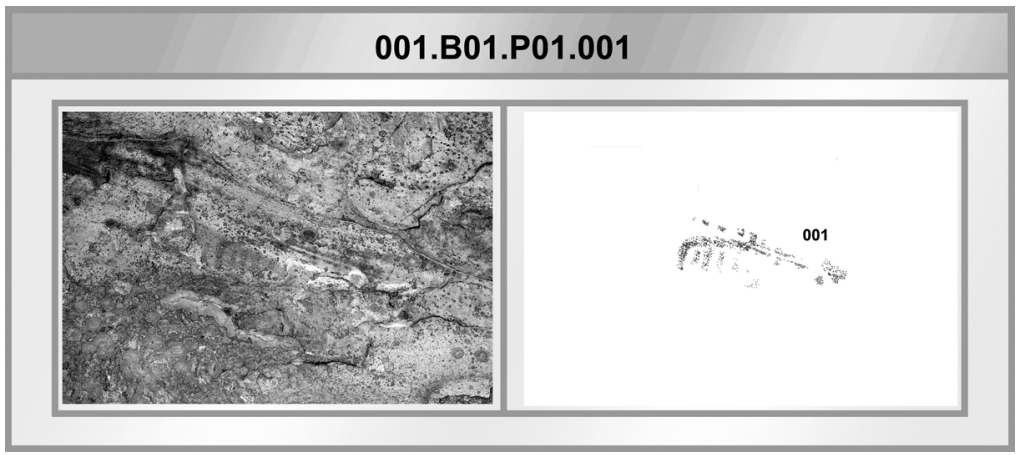

Fig. 3. Bacinete I. Reproducción digital. 


\subsection{Bacinete II}

Localización: (Coordenadas UTM) X: 270.45 , Y: 4009.70. Mapa Topográfico Nacional de España. Escala 1:25.000. Zanona. 1074-IV. Instituto Geográfico Nacional.

Morfología: Abrigo rocoso (2.2 (altura) $\times 4.1$ (anchura) $\times 1.1 \mathrm{~m}$ (profundidad)).

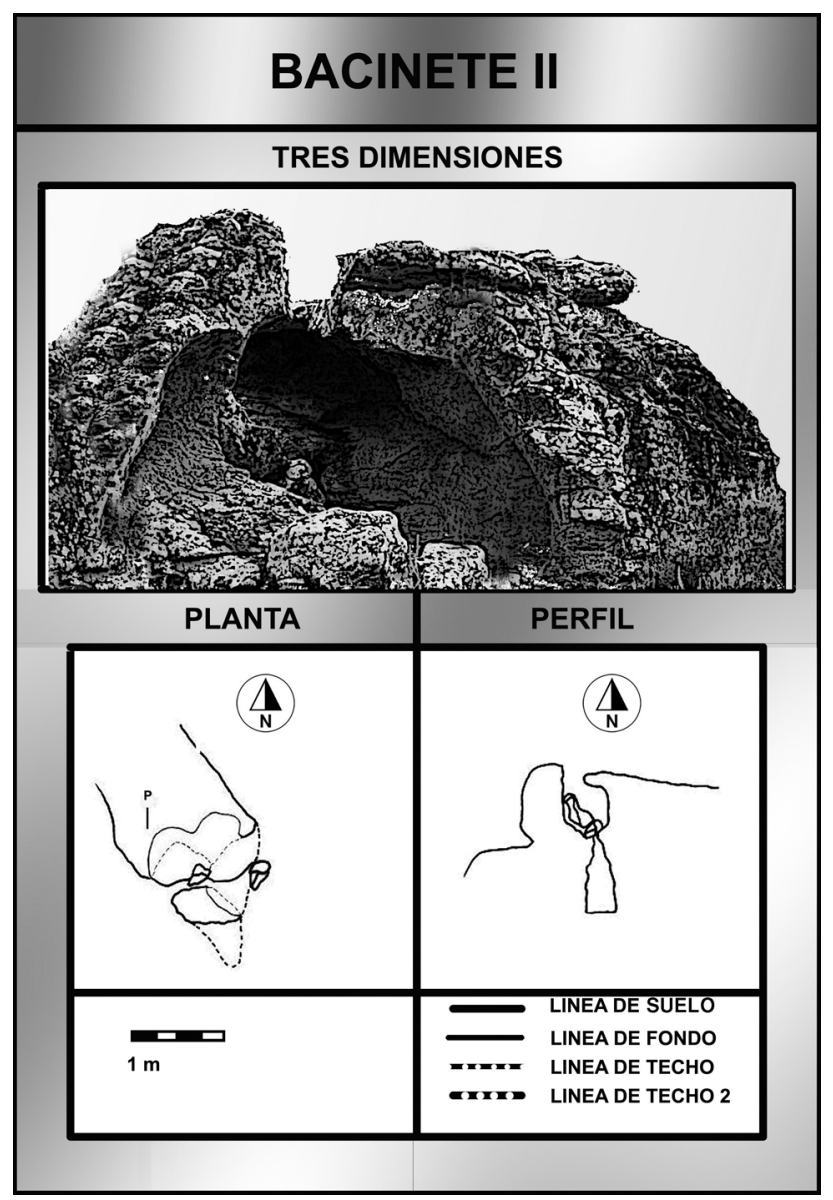

Fig. 4. Bacinete II. Planta y perfil.

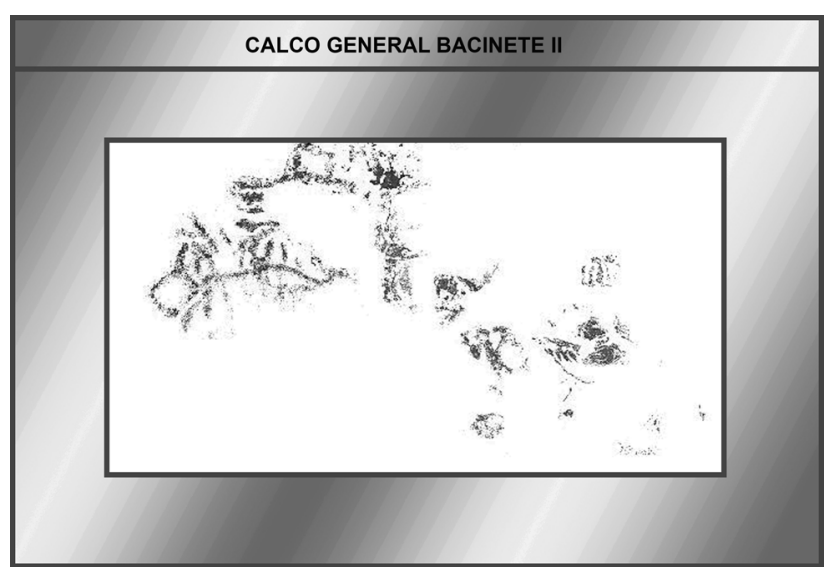

Fig. 5. Bacinete II. Reproducción digital. 


\subsection{Bacinete III}

Localización: (Coordenadas UTM) X: 270.20, Y: 4009.15. Mapa Topográfico Nacional de España. Escala 1:25.000. Zanona. 1074-IV. Instituto Geográfico Nacional.

Morfología: Abrigo rocoso (3.8 (altura) $\times 8.3$ (anchura) $\times 2.8 \mathrm{~m}$ (profundidad)).

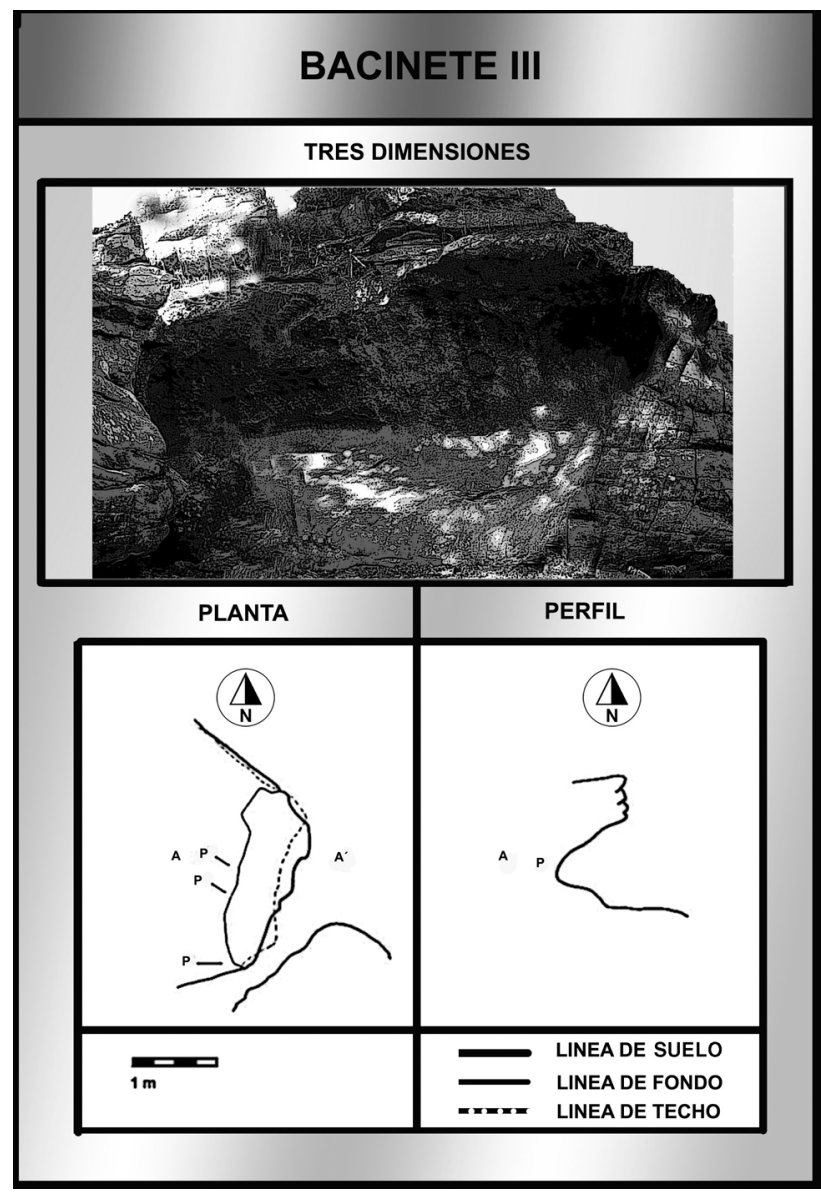

Fig. 6. Bacinete III. Planta y perfil.

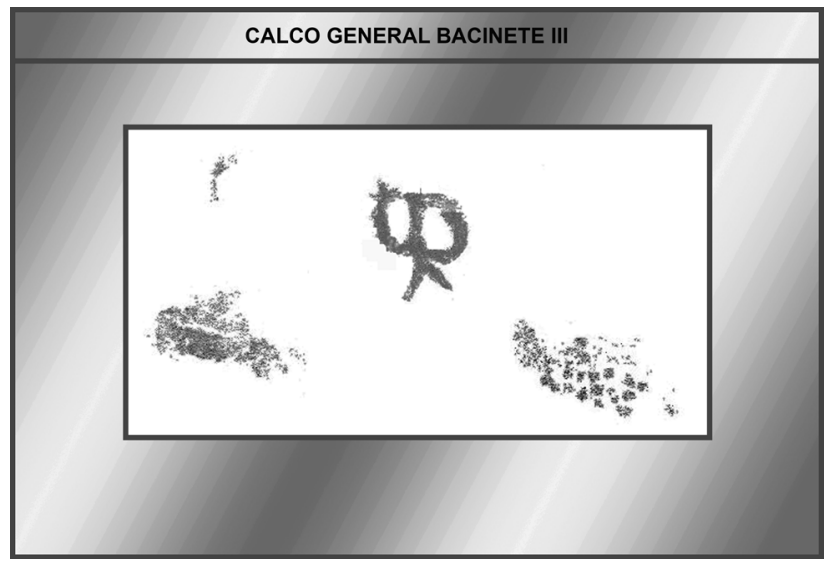

Fig. 7. Bacinete III. Reproducción digital. 


\subsection{Bacinete IV}

Localización: (Coordenadas UTM) X: 270.10, Y: 4009.20. Mapa Topográfico Nacional de España. Escala 1:25.000. Zanona. 1074-IV. Instituto Geográfico Nacional.

Morfología: Abrigo rocoso (1.6 (altura) $\times 4.6$ (anchura) $\times 2.9 \mathrm{~m}$ (profundidad)). Se trata de la pared cóncava orientada hacía el norte del gran bloque prismático que contiene en su lado sur Bacinete VIII (Gran Abrigo).

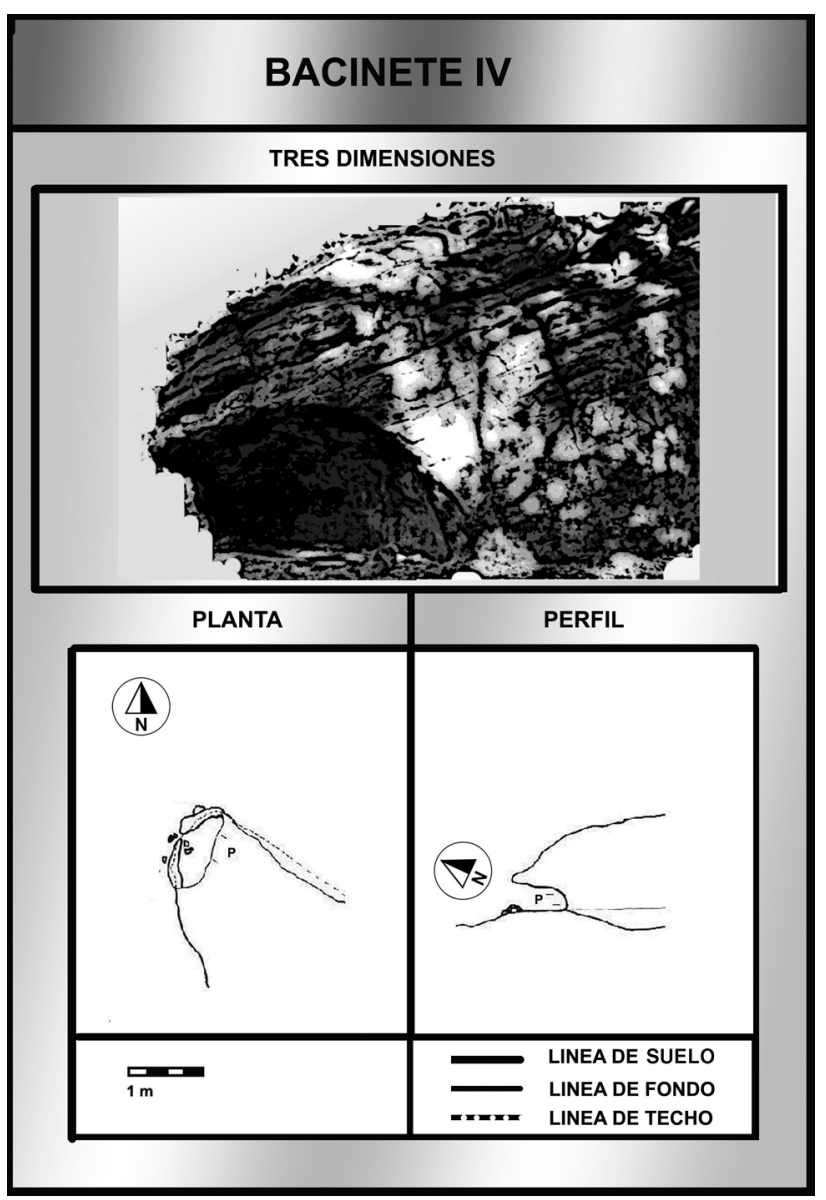

Fig. 8. Bacinete IV. Planta y perfil.

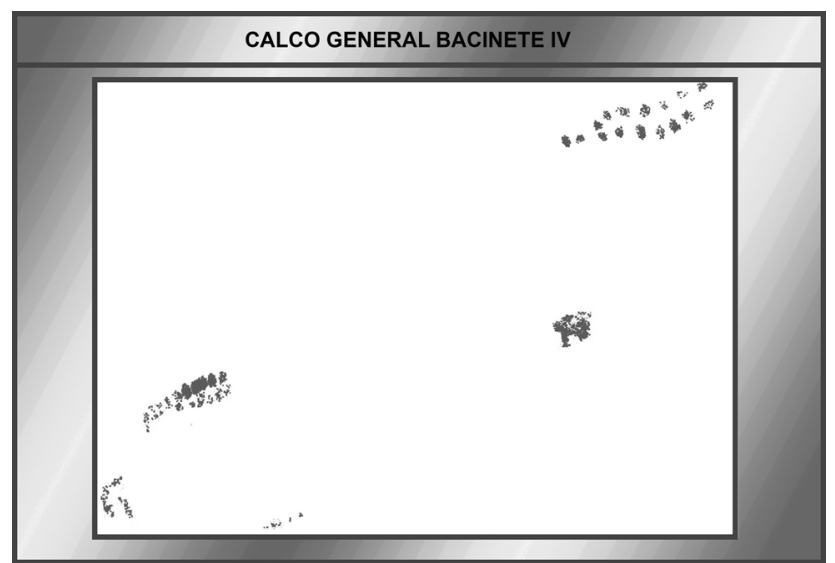

Fig. 9. Bacinete IV. Reproducción digital. 


\subsection{Bacinete $V$}

Localización: (Coordenadas UTM) X: 270.05, Y: 4009.10. Mapa Topográfico Nacional de España. Escala 1:25.000. Zanona. 1074-IV. Instituto Geográfico Nacional.

Morfología: Cavidad formada por el derrumbe de un bloque prismático (la base se encuentra parcialmente corroída) sobre otro bloque, $A-A^{\prime}(2.8$ (altura) $\times 8.0$ m (anchura)), B-B' (6.4 m (profundidad)), C-C' (2.5 m (anchura)) C1-C2 (2.2 m (altura)).

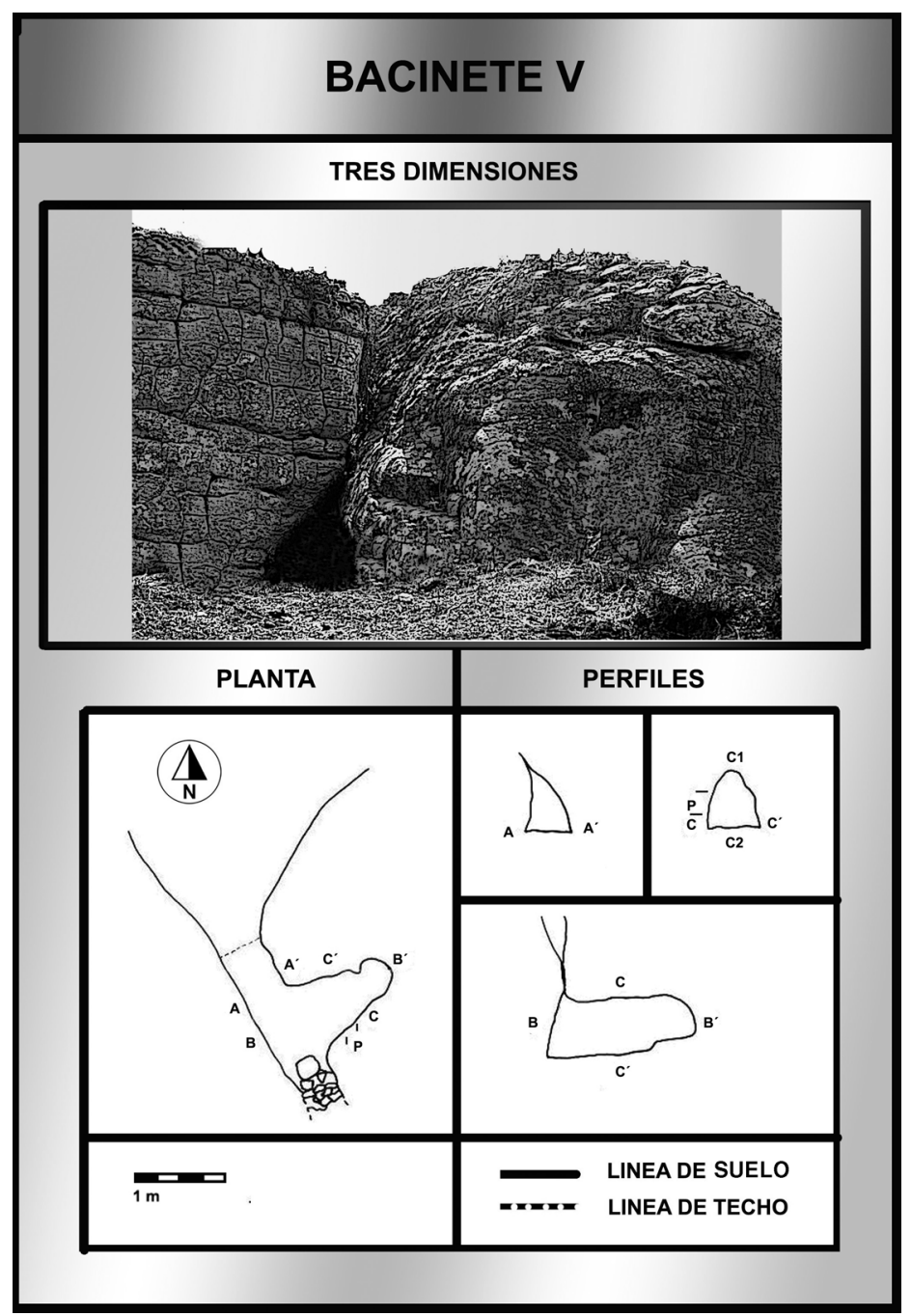

Fig. 10. Bacinete V. Planta y perfil. 


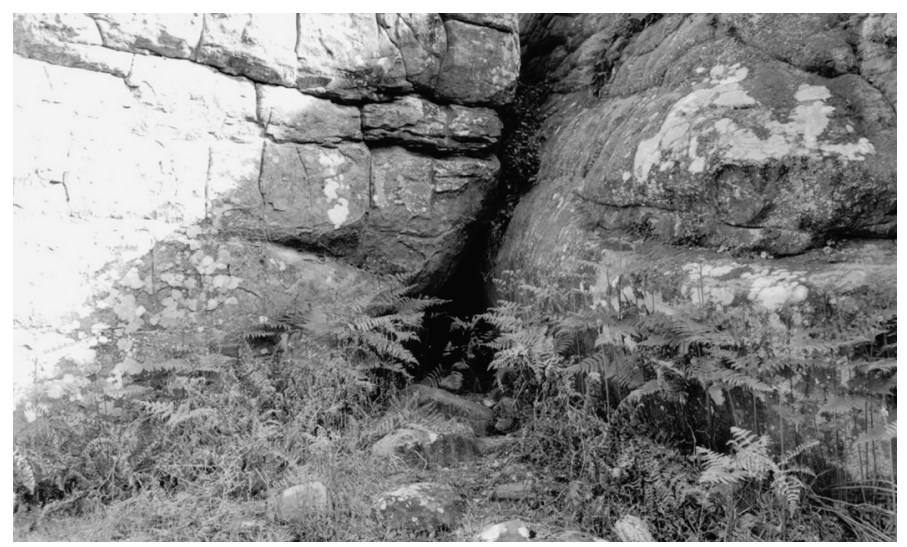

Fig. 11. Bacinete V. Entrada.

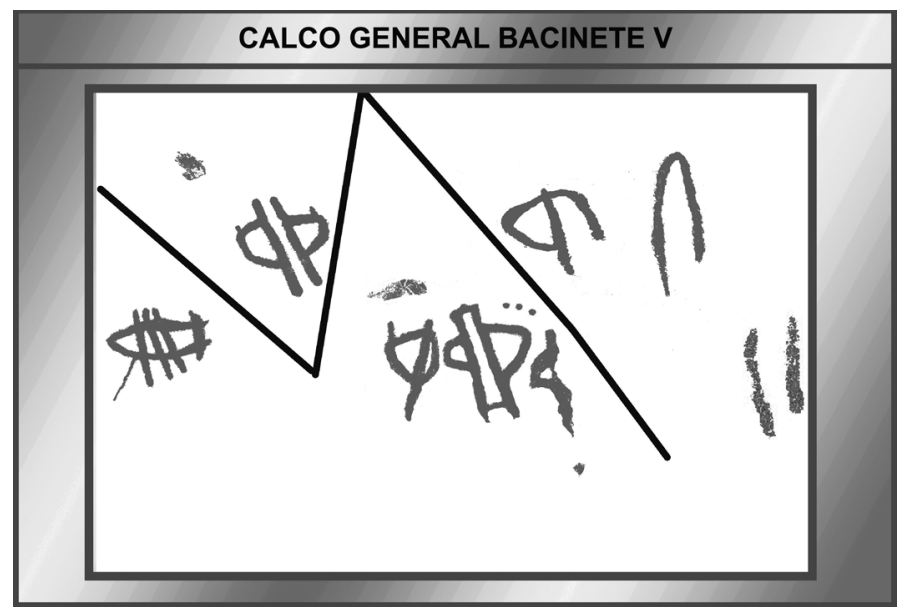

Fig. 12. Bacinete V. Reproducción digital.

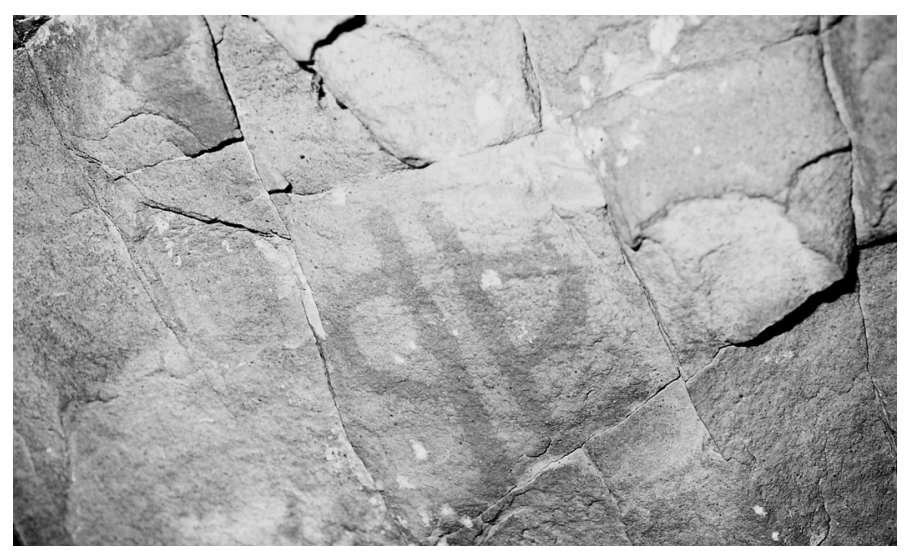

Fig. 13. Bacinete V. Detalle de motivo. 


\subsection{Bacinete VI}

Localización: (Coordenadas UTM) X: 270.25, Y: 4009.34. Mapa Topográfico Nacional de España. Escala 1:25.000. Zanona. 1074-IV. Instituto Geográfico Nacional.

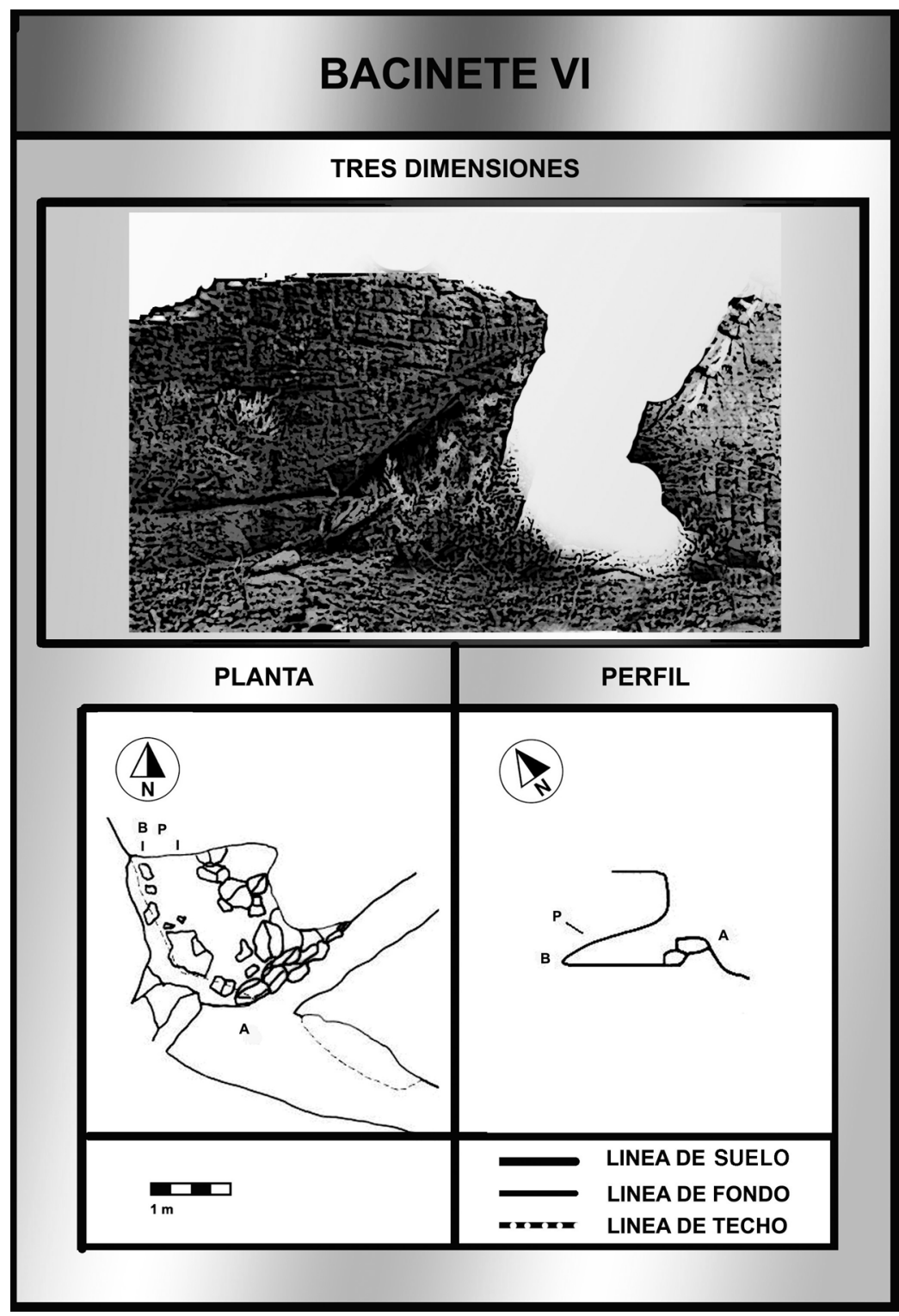

Fig. 14. Bacinete VI. Planta y perfil. 
Morfología: Abrigo rocoso $(2.1$ (altura) $\times 8.2$ (anchura) $\times 3.9 \mathrm{~m}$ (profundidad))

\section{CALCO GENERAL BACINETE VI}

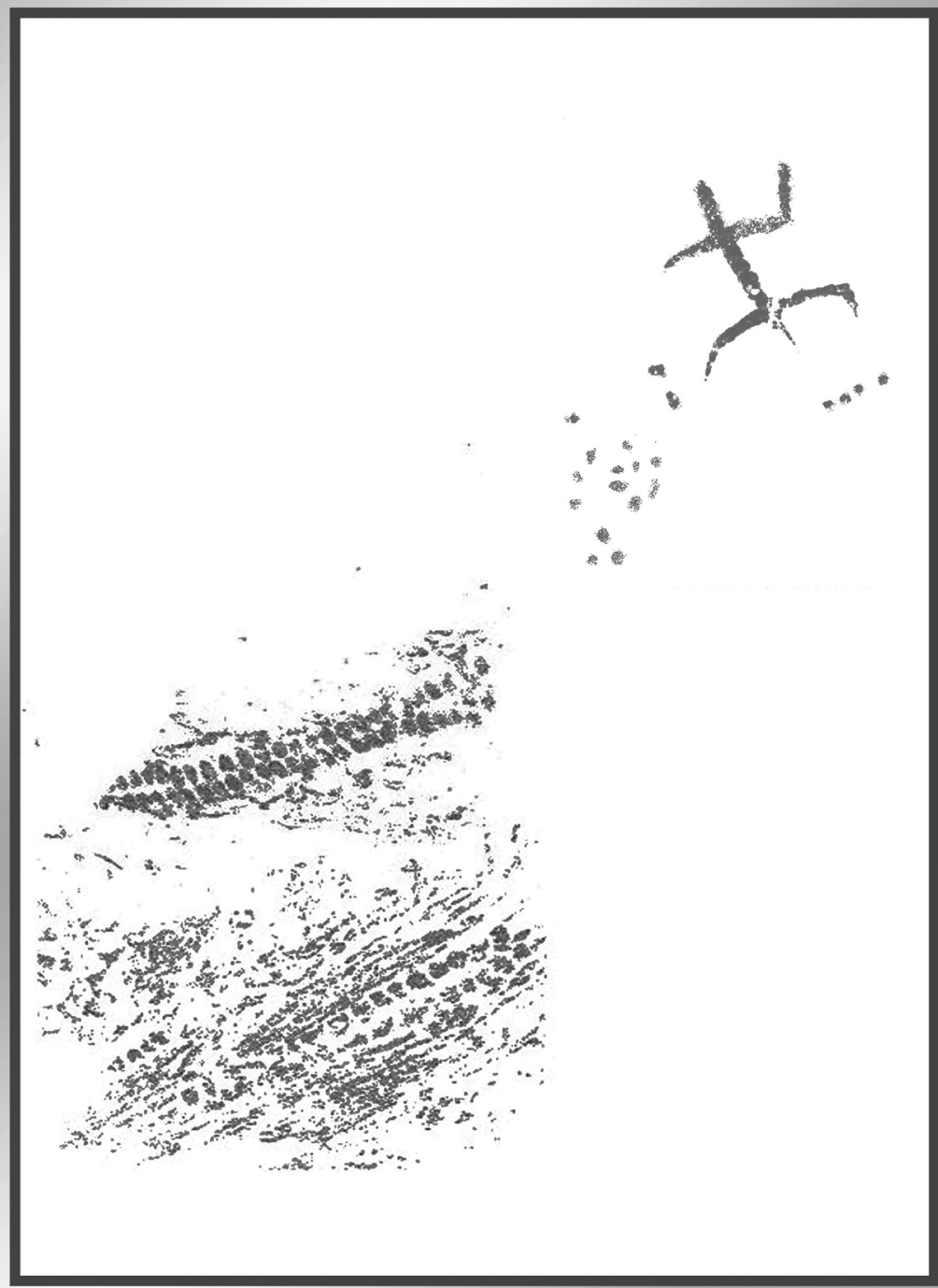

Fig. 15. Bacinete VI. Reproducción digital. 


\subsection{Bacinete VII}

Localización: (Coordenadas UTM) $\mathrm{X}$ : 270.27, Y: 4009.40. Mapa Topográfico Nacional de España. Escala 1:25.000. Zanona. 1074-IV. Instituto Geográfico Nacional.

Morfología: Abrigo rocoso (1.7 (altura) $\times$ 10.9 (anchura) $\times 1.9$ $\mathrm{m}$ (profundidad)).

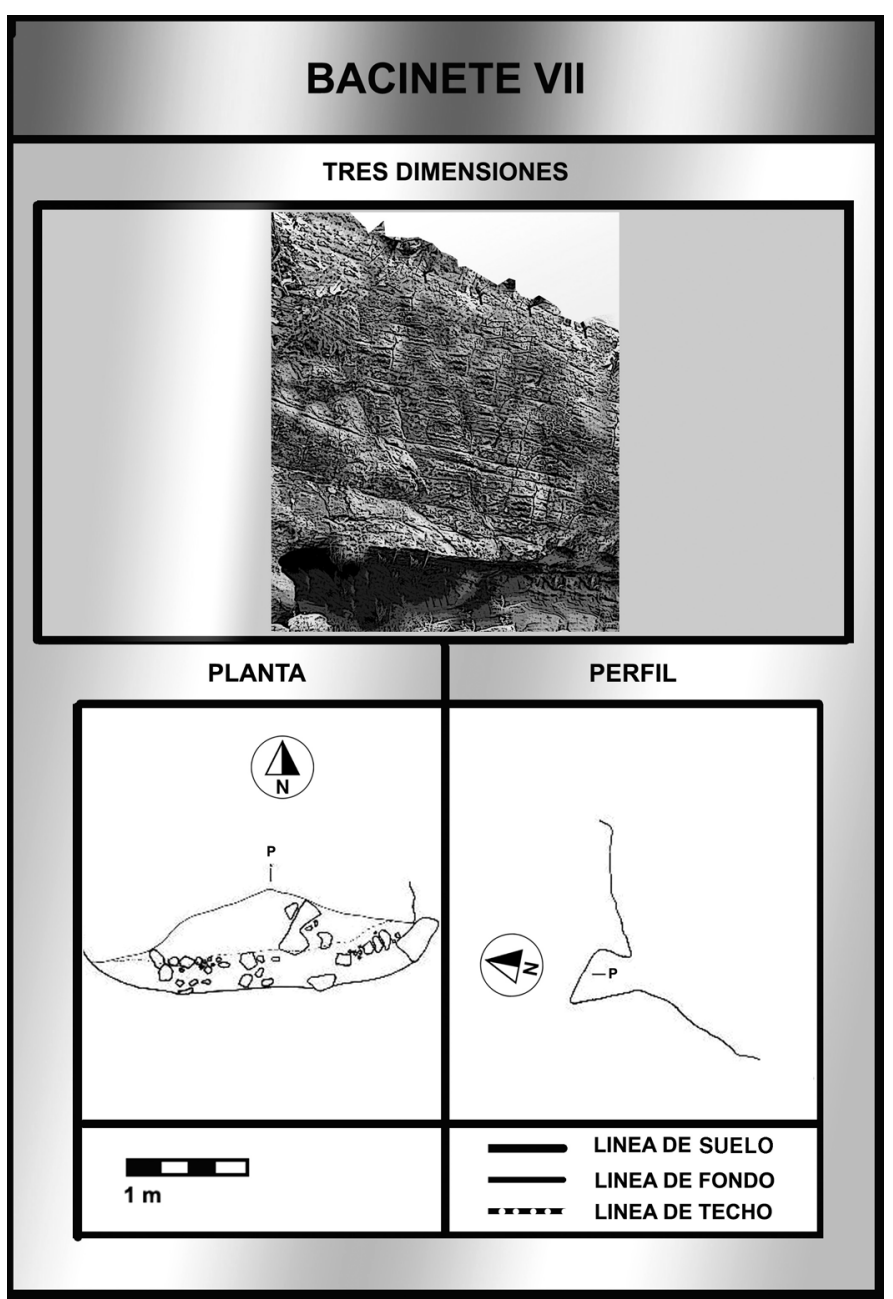

Fig. 16. Bacinete VII. Planta y perfil.

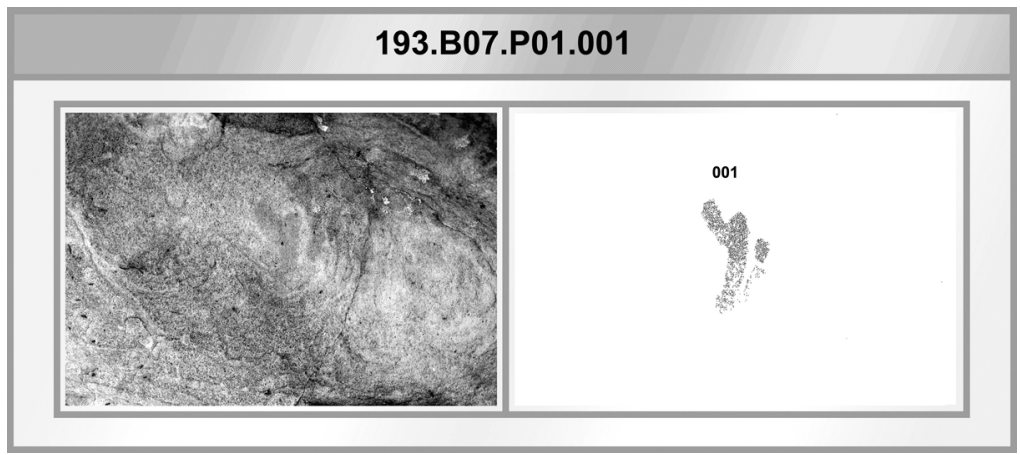

Fig. 17. Bacinete VII. Reproducción digital. 


\subsection{Bacinete VIII (Gran Abrigo)}

Localización: (Coordenadas UTM) X: 270.10, Y: 4009.20. Mapa Topográfico Nacional de España. Escala 1:25.000. Zanona. 1074-IV. Instituto Geográfico Nacional.

Morfología: Abrigo rocoso (2.9 (altura) $\times 9.6$ (anchura) $\times$ $3.10 \mathrm{~m}$ (profundidad)). Se trata de la pared cóncava orientada hacía el sur del gran bloque prismático que contiene en su lado norte Bacinete IV.

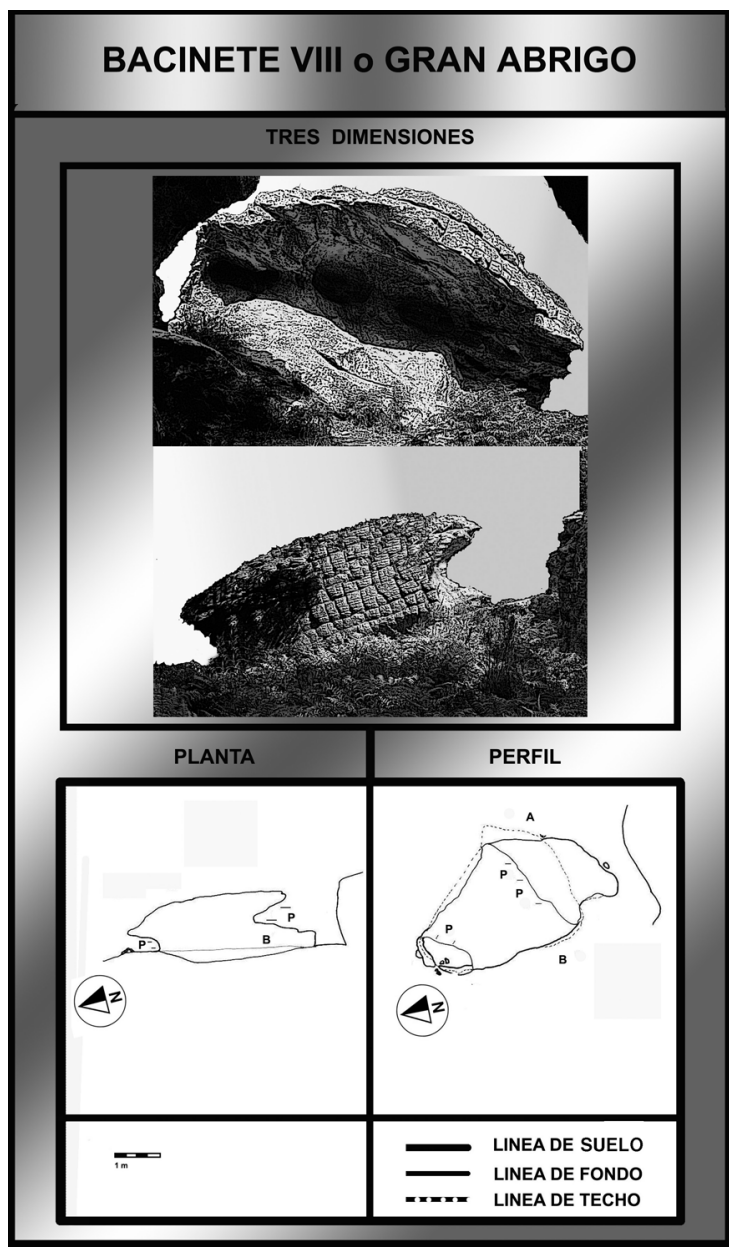

Fig. 18. Bacinete VIII o Gran Abrigo. Planta y perfil.

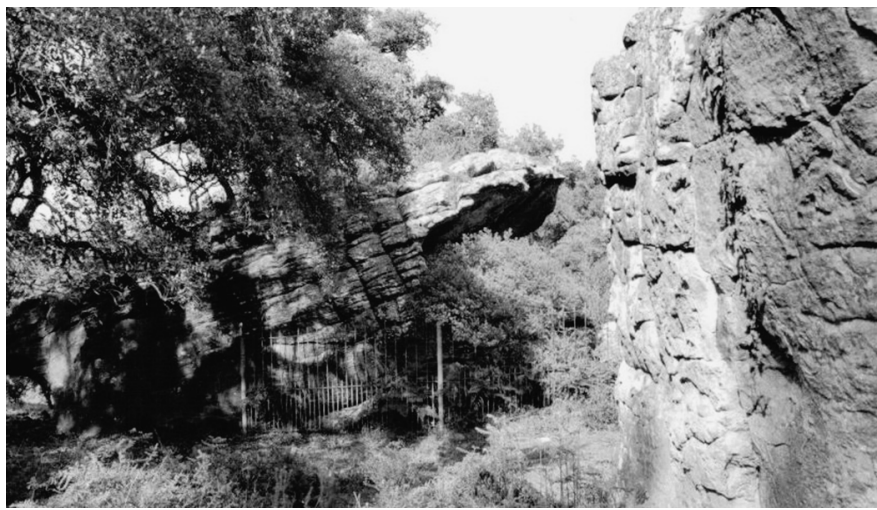

Fig. 19. Vista de Bacinete VIII o Gran Abrigo. 
El Gran Abrigo o Bacinete VIII contiene un panel decorado en su pared rocosa que abarca parte del techo.

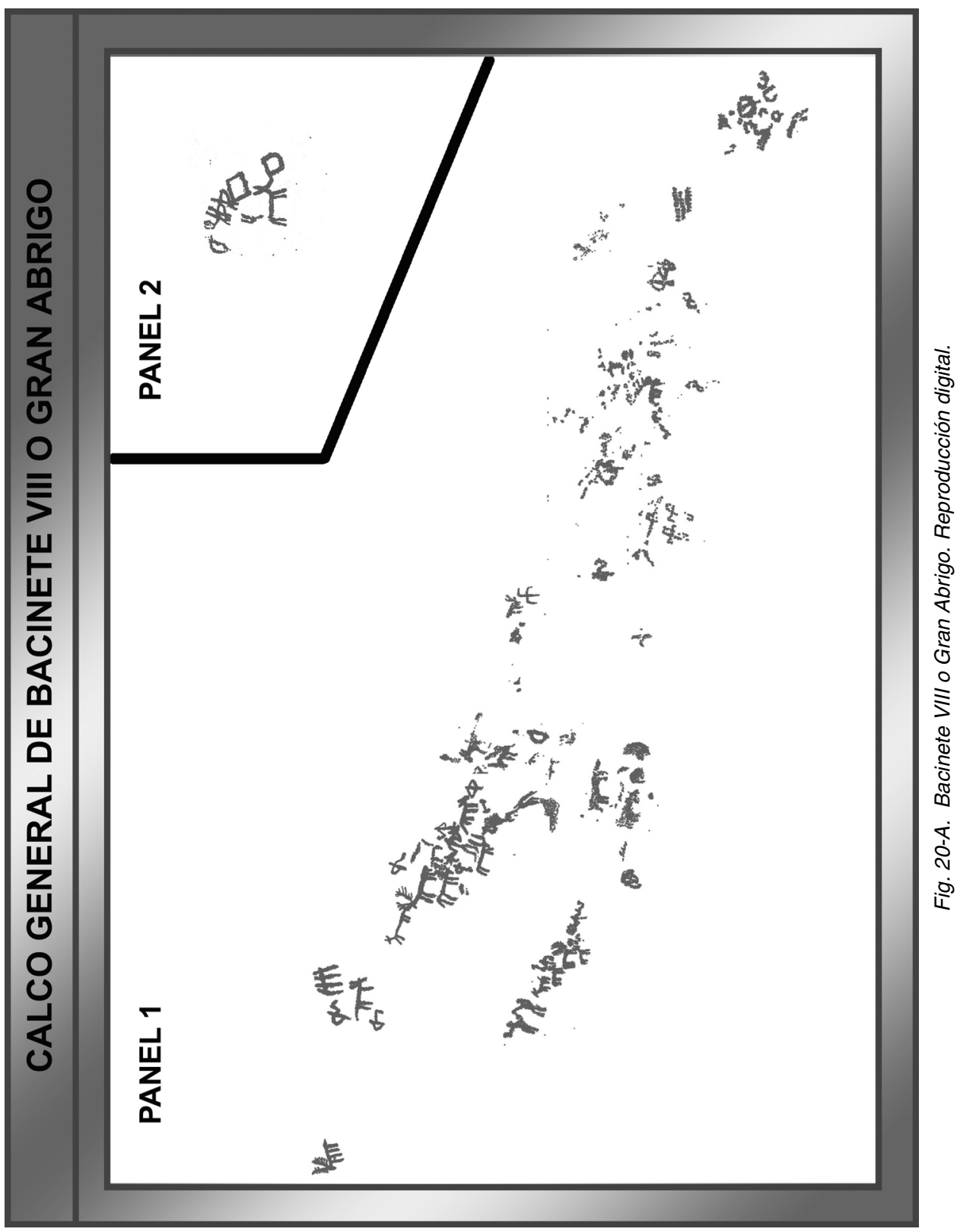




\section{B08.P01.001}
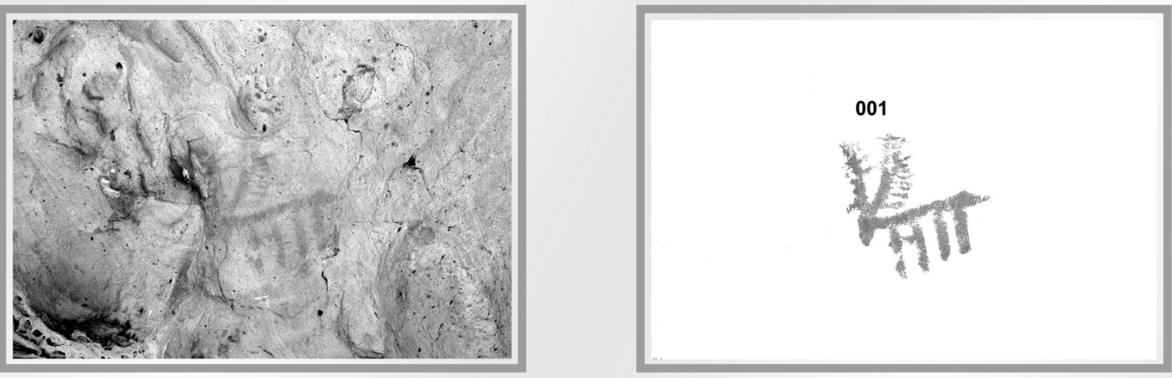

Fig. 20-B. Bacinete VIII o Gran Abrigo. Reproducción digital.

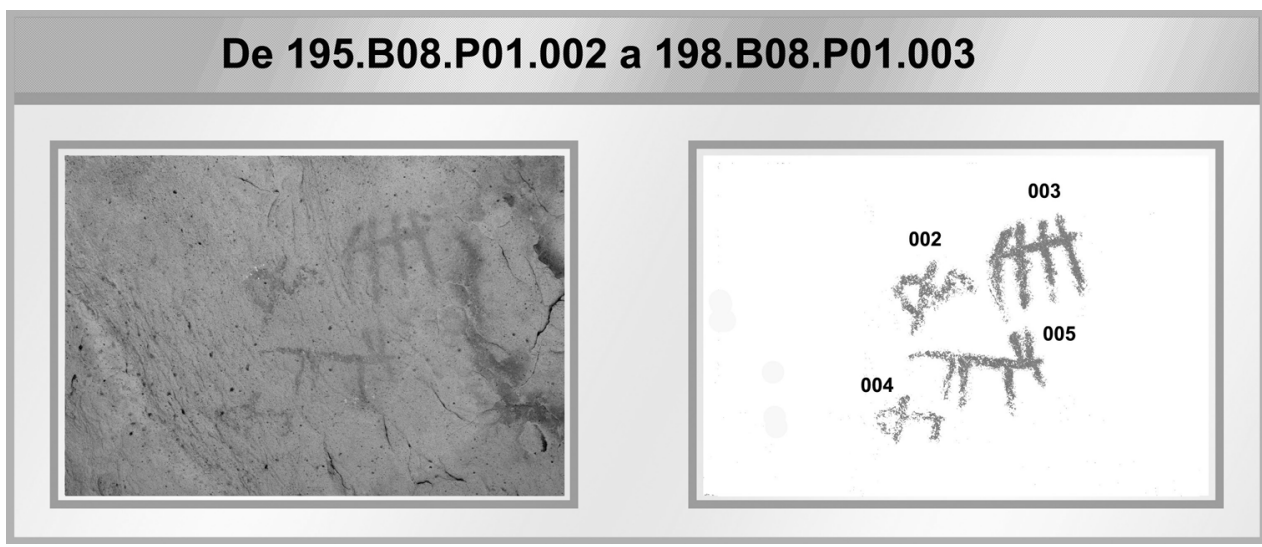

Fig. 20-C. Bacinete VIII o Gran Abrigo. Reproducción digital.

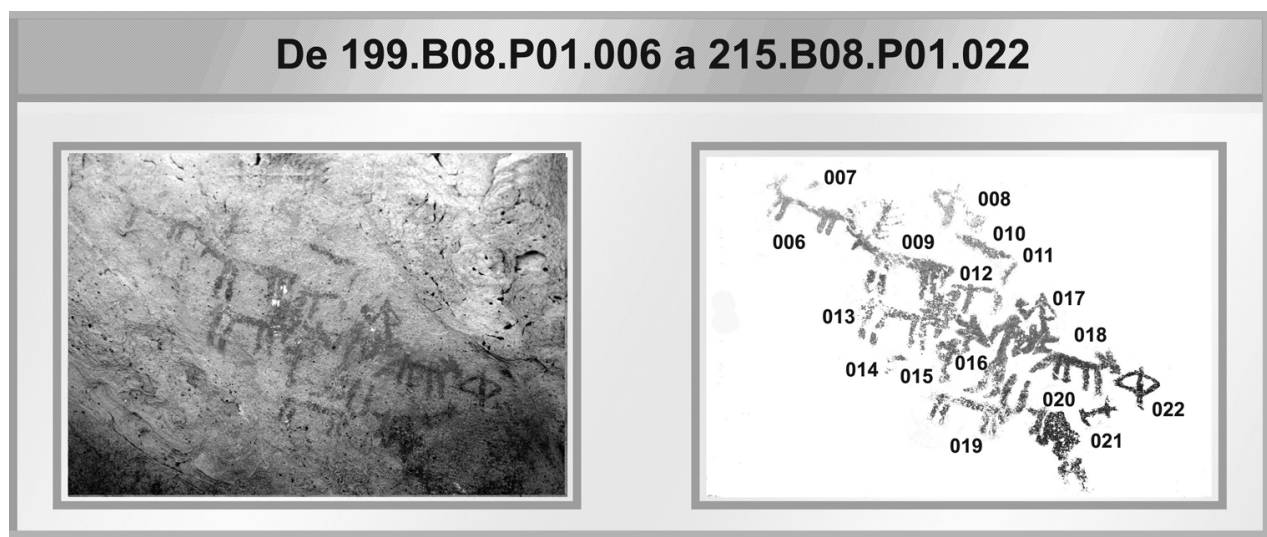

Fig. 20-D. Bacinete VIII o Gran Abrigo. Reproducción digital. 


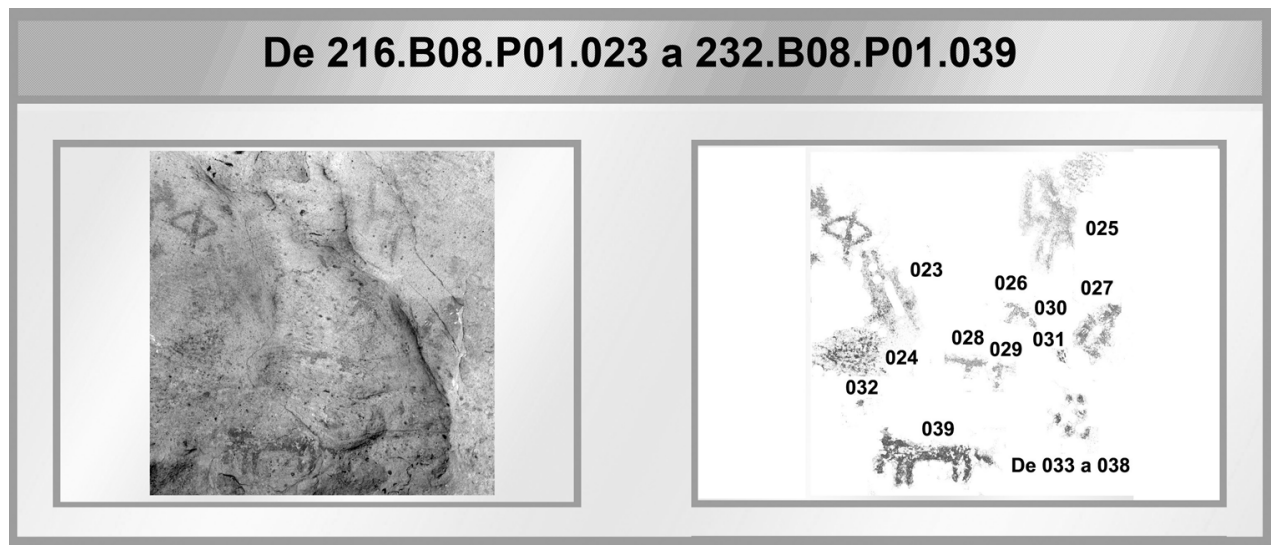

Fig. 20-E. Bacinete VIII o Gran Abrigo. Reproducción digital.

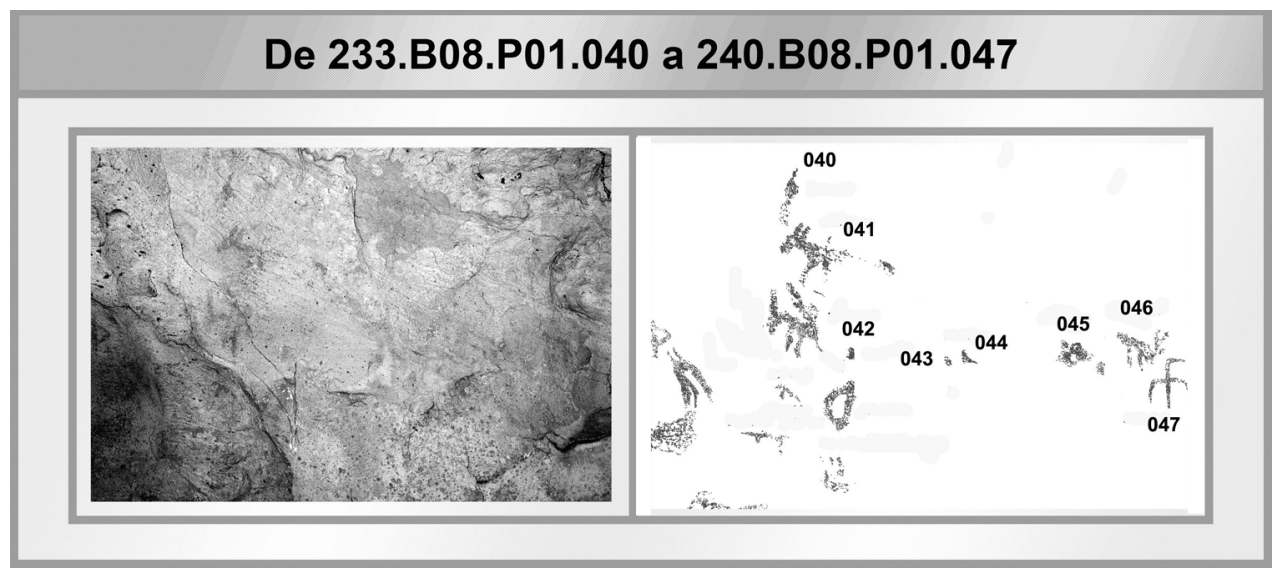

Fig. 20-F. Bacinete VIII o Gran Abrigo. Reproducción digital.

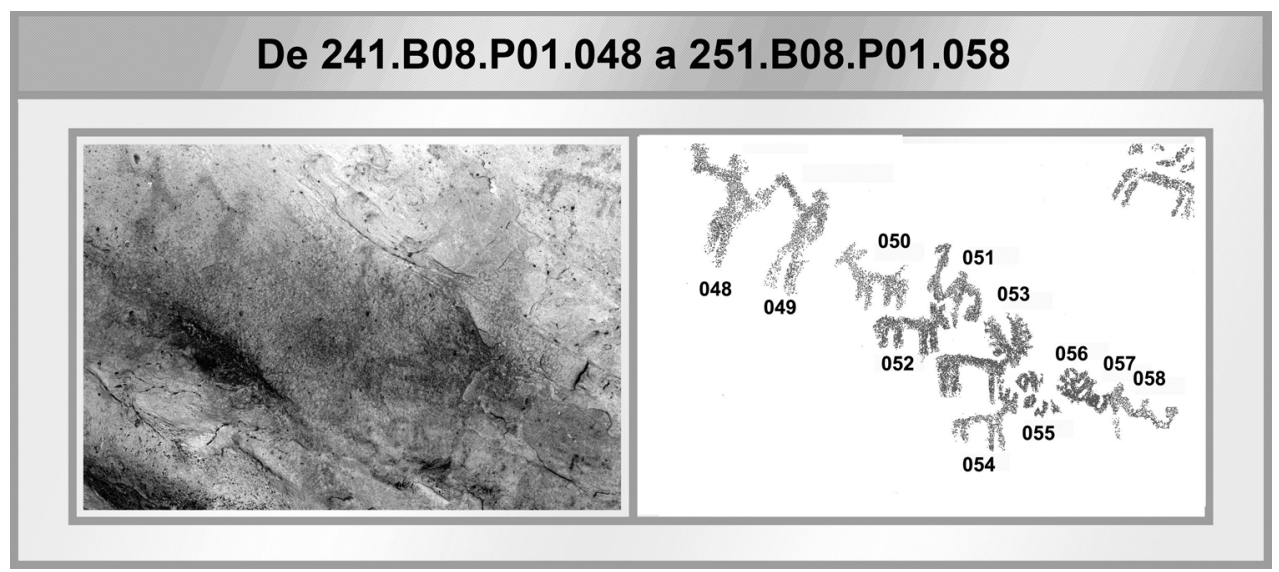

Fig. 20-G. Bacinete VIII o Gran Abrigo. Reproducción digital. 


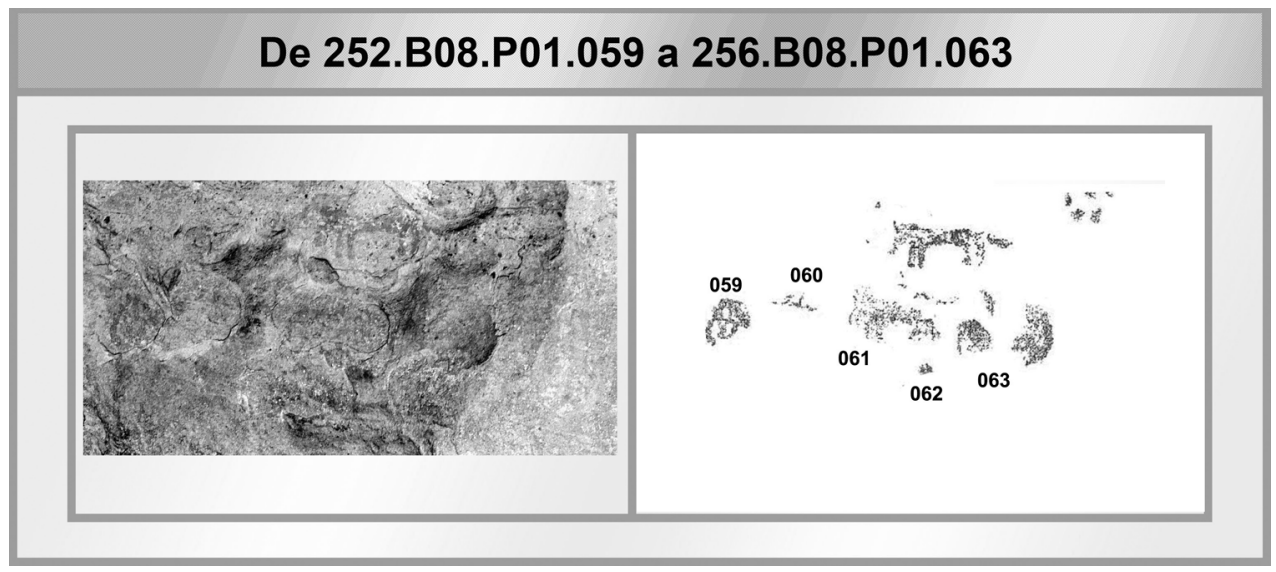

Fig. 20-H. Bacinete VIII o Gran Abrigo. Reproducción digital.

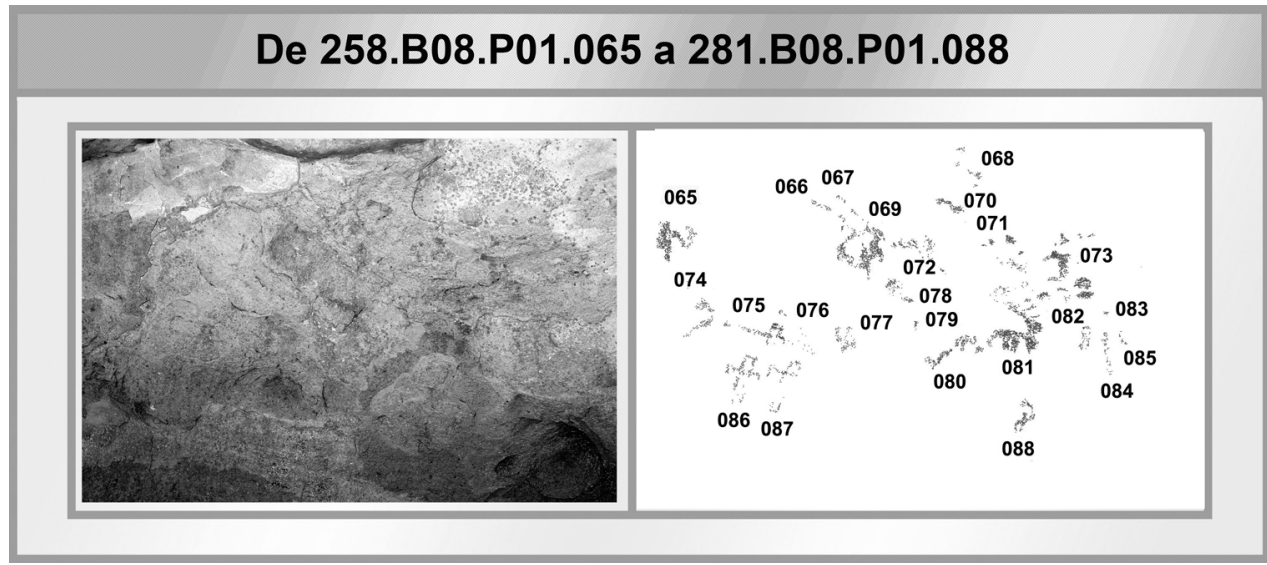

Fig. 20-I. Bacinete VIII o Gran Abrigo. Reproducción digital.

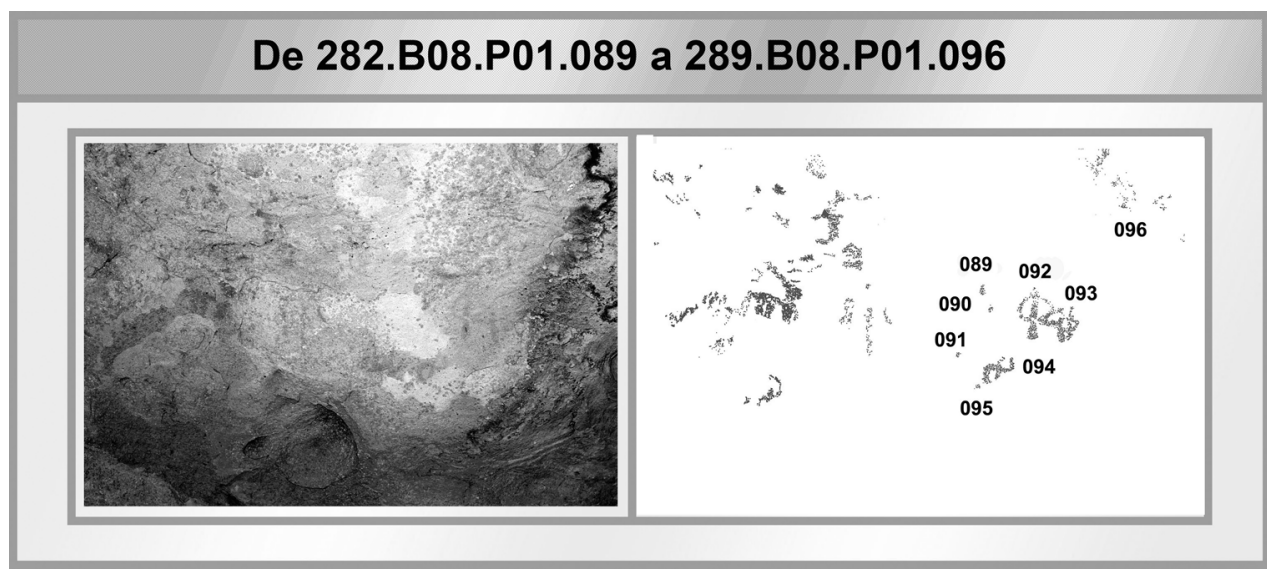

Fig. 20-J. Bacinete VIII o Gran Abrigo. Reproducción digital. 


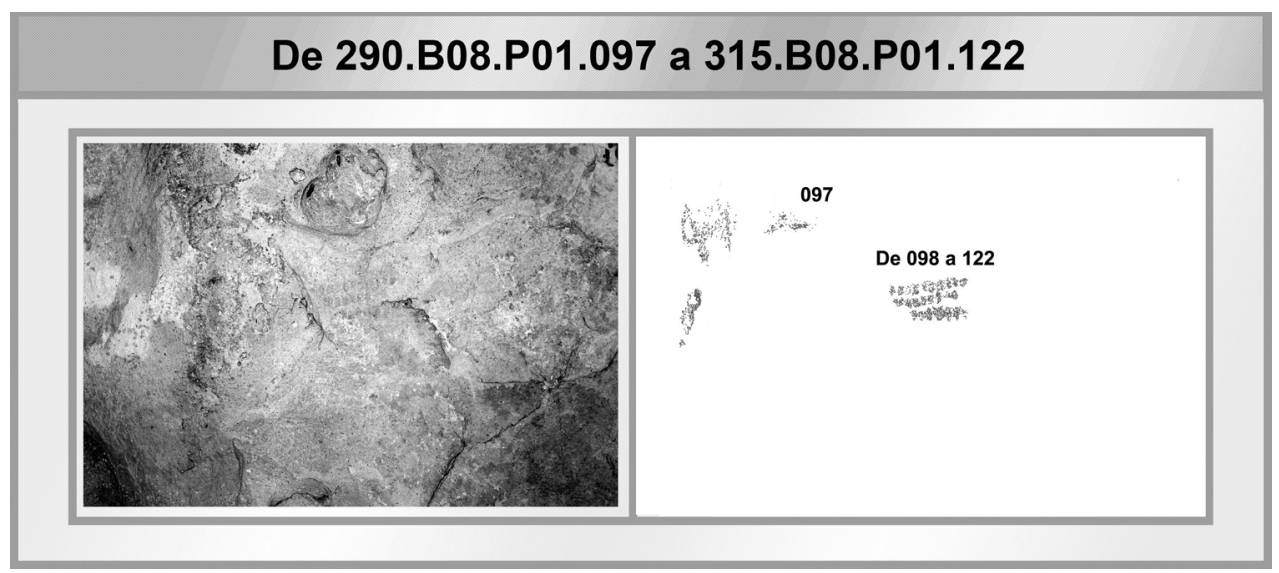

Fig. 20-K. Bacinete VIII o Gran Abrigo. Reproducción digital.

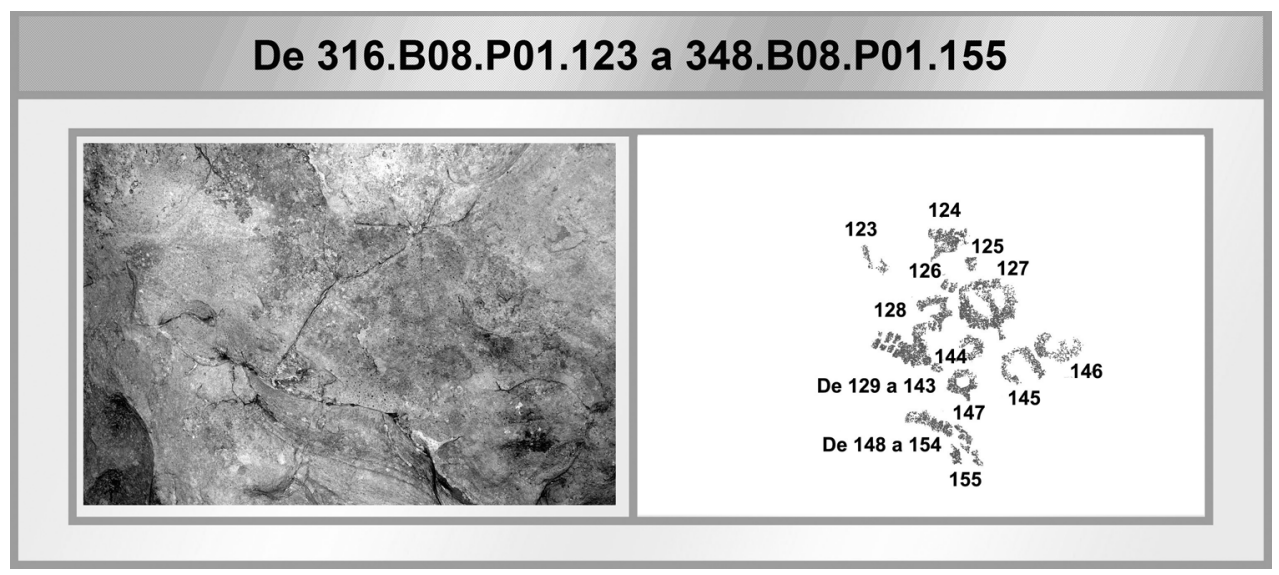

Fig. 20-L. Bacinete VIII o Gran Abrigo. Reproducción digital.

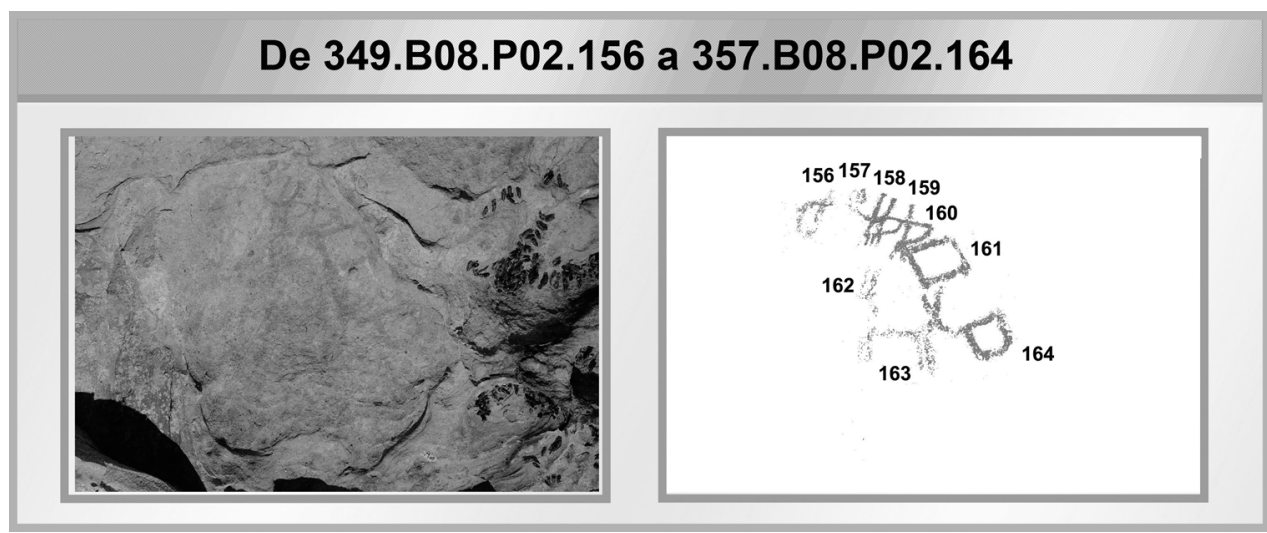

Fig. 20-M. Bacinete VIII o Gran Abrigo. Reproducción digital. 


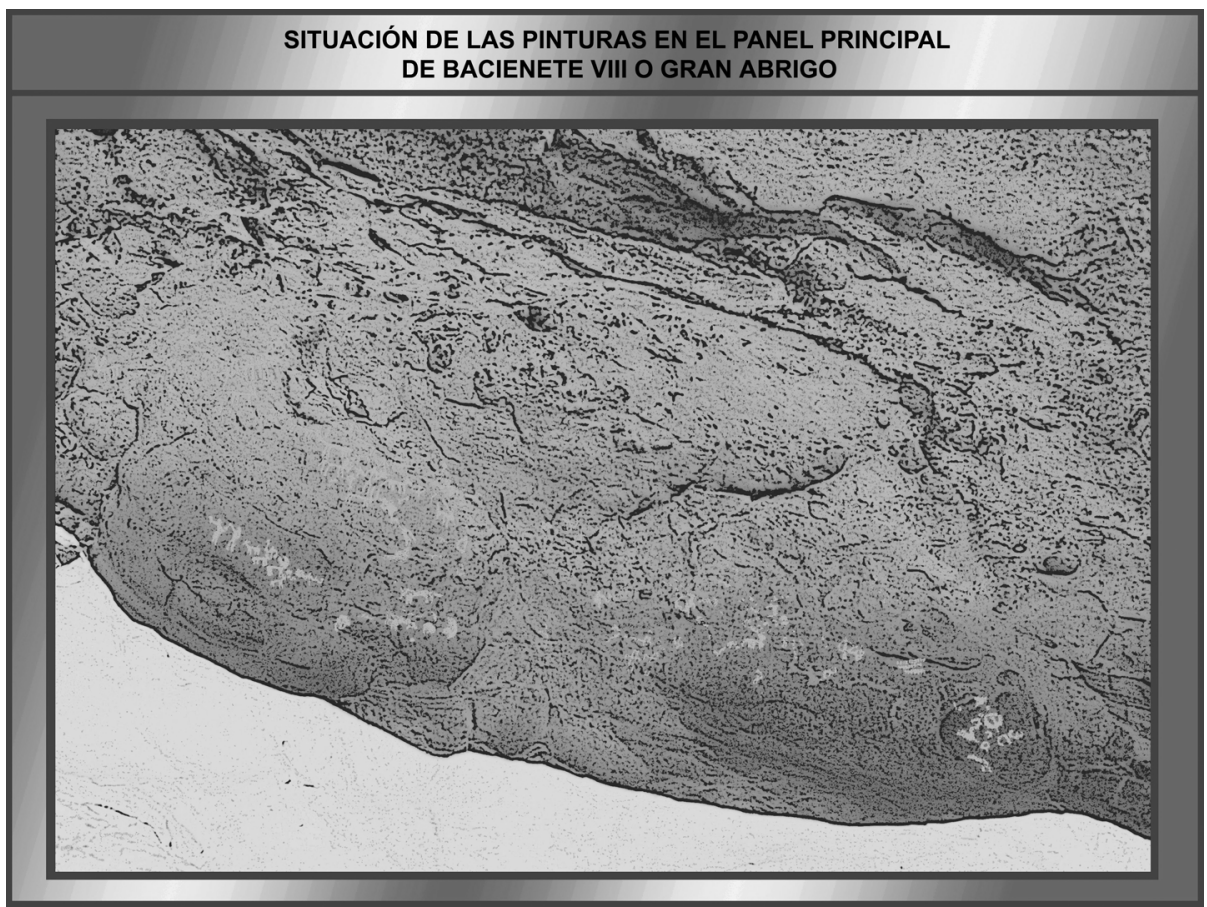

Fig. 21. Bacinete VIII o Gran Abrigo. Vista del panel decorado.

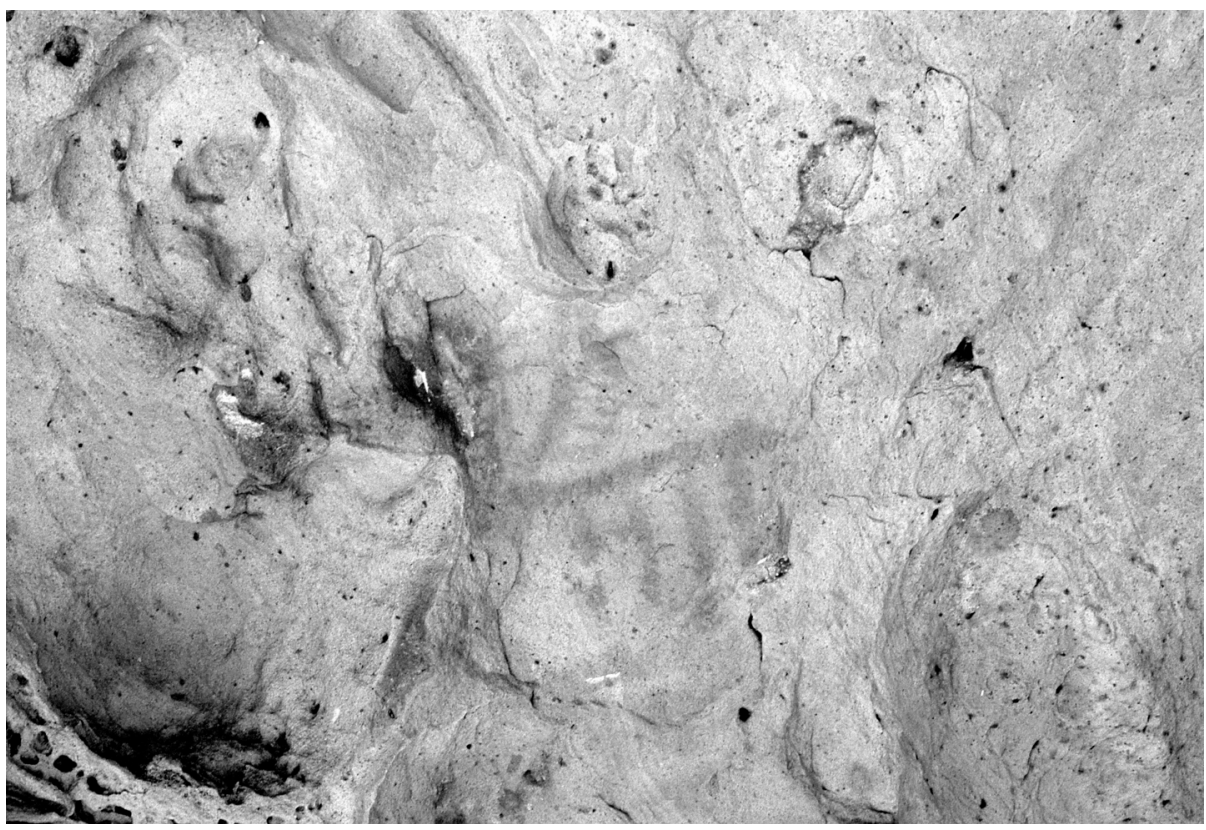

Fig. 22. Bacinete VIII o Gran Abrigo. Cérvido. 


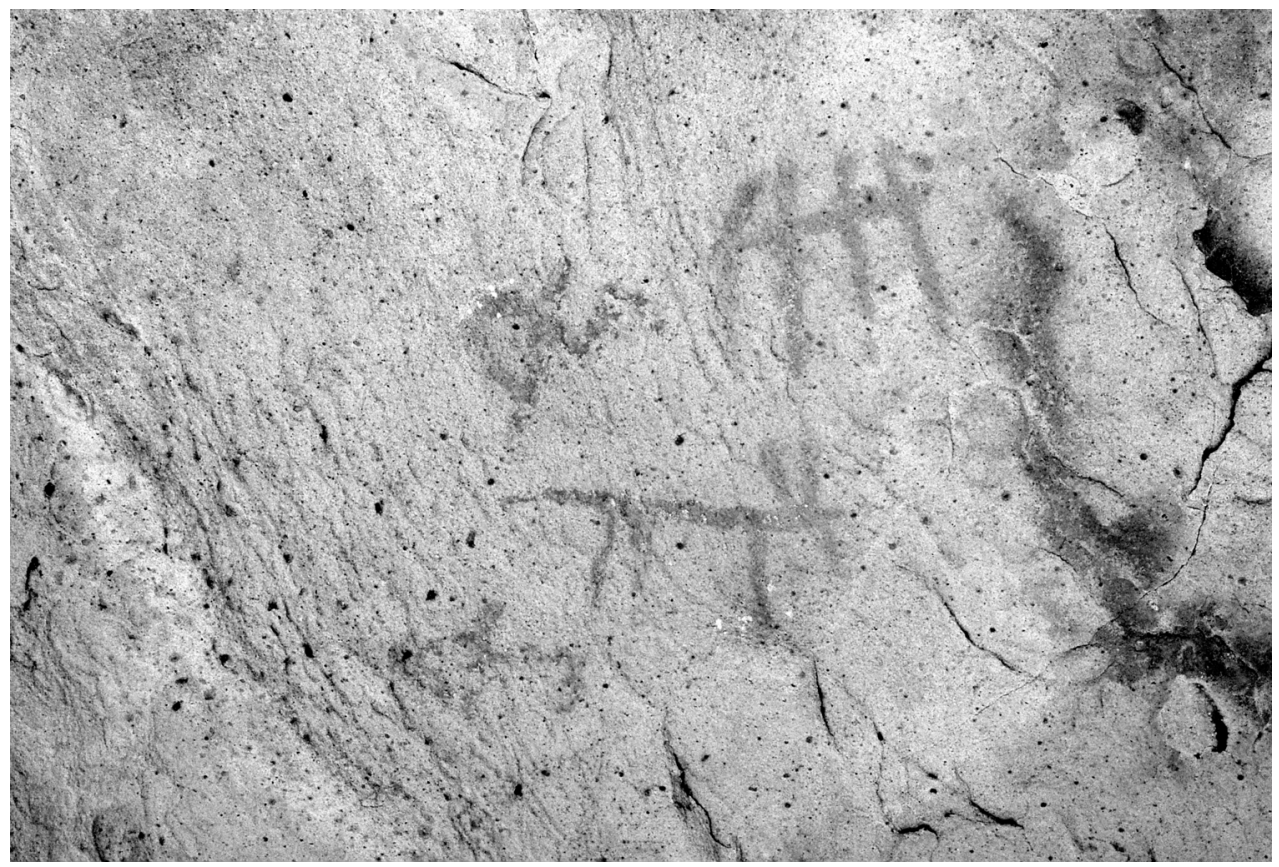

Fig. 23. Bacinete VIII o Gran Abrigo. Escena.

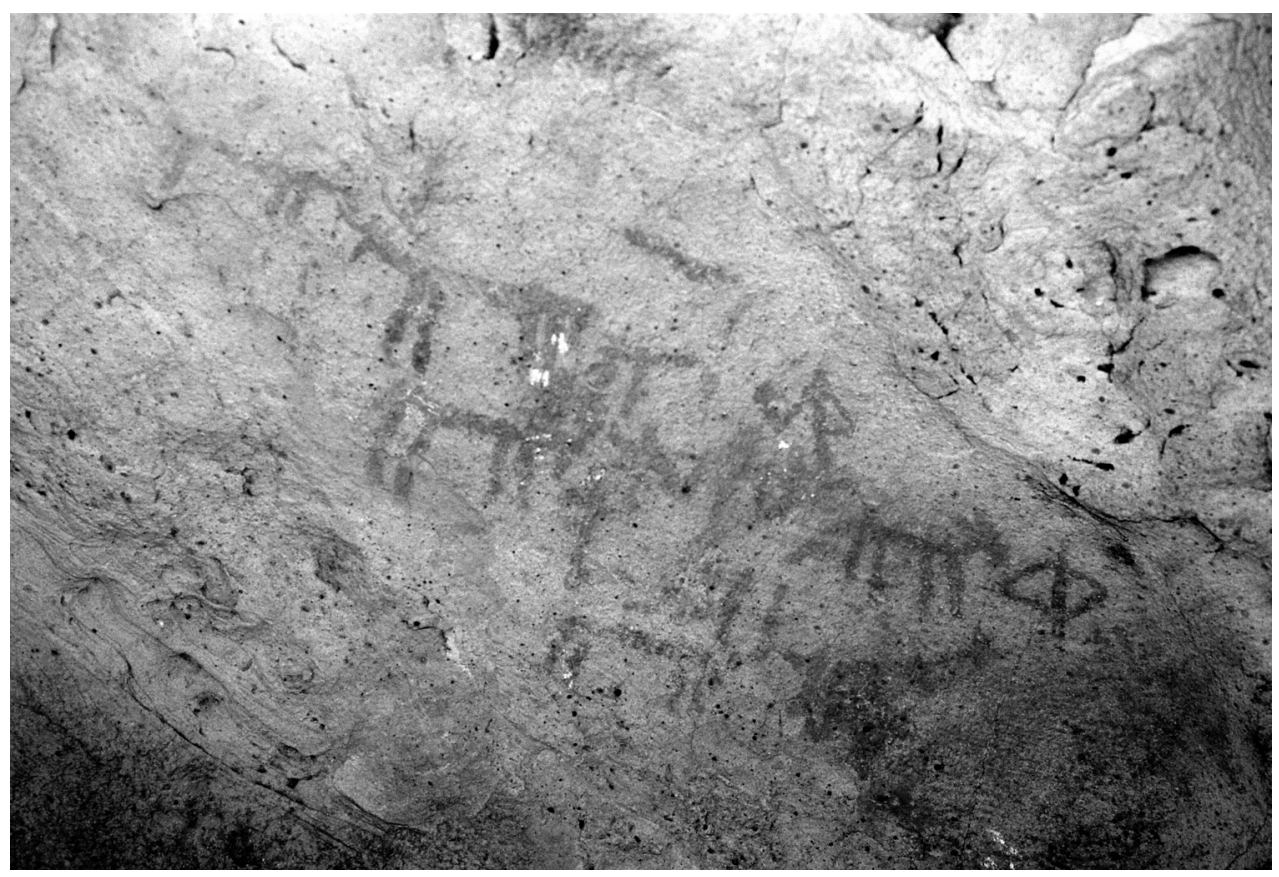

Fig. 24. Bacinete VIII o Gran Abrigo. Detalle del panel central. 


\section{ANÁLISIS TIPOLÓGICO}

\subsection{Bacinete I}

En la cavidad denominada Bacinete I solo se ha localizado un único motivo bastante deteriorado, tras el tratamiento digitalizado y la observación del calco de H. Breuil (Breuil y Burkitt, 1929), se ha interpretado como los restos de un pectiniforme doble, por tanto el $100 \%$ de la cavidad se incluiría dentro de una secuencia esquemática.

\subsection{Bacinete II}

El abrigo denominado Bacinete II ha resultado ser una amalgama de restos, entre los que se encuentra una figura de dimensiones considerables, una combinación de elementos, en la que se encuentra imbricada un antropomorfo esquemático, por ello a la hora de elaborar las estadísticas se ha priorizado la parte identificable de este motivo.

Hay que destacar la ausencia de motivos de tendencia naturalista, siendo por tanto en su totalidad una cavidad inserta en la secuencia esquemática.

De un total de siete motivos, se han distinguido cuatro tipos:

1. A: Antropomorfos.

2. CU: Cuadrangulares.

3. R: Restos.

4. NI: Figuras no identificables.

\begin{tabular}{|c|c|c|c|}
\hline $\mathbf{A}$ & CU & $\mathbf{R}$ & $\mathbf{N I}$ \\
\hline 1 & 1 & 3 & 2 \\
\hline $14 \%$ & $14 \%$ & $43 \%$ & $29 \%$ \\
\hline
\end{tabular}

De lo que se deduce que el $86 \%$ de los motivos pintados en Bacinete II no son identificables con elementos reales ${ }^{10}$ o de temática naturalista. El único motivo encuadrable dentro de una temática naturalista es un antropomorfo estilísticamente esquemático.

10 Reales desde el punto de vista de un espectador actual. 


\subsection{Bacinete III}

El abrigo denominado Bacinete III es posiblemente el más expuesto a la acción del viento de Levante, de ahí el acusado deterioro de sus motivos, es probable que en origen esta cavidad contara con mayor número de motivos de los que se pueden apreciar hoy. El estado actual del panel permite distinguir veintidós motivos, entre los que se distinguen las siguientes tipologías:

1. A: Antropomorfos.

2. P: Puntos.

3. R: Restos.

\begin{tabular}{|c|c|c|}
\hline $\mathbf{A}$ & $\mathbf{P}$ & $\mathbf{R}$ \\
\hline 1 & 18 & 3 \\
\hline $5 \%$ & $81 \%$ & $14 \%$ \\
\hline
\end{tabular}

Sin duda, los motivos dominantes en esta cavidad son los puntos, todos ellos en asociación lineal. Hay que destacar además la ausencia de motivos de tendencia naturalista. Por otra parte, el único antropomorfo, estilísticamente esquemático que aparece, se sitúa en la parte central del panel, aunque porcentualmente su importancia es conforme a criterios estadísticos menor, por su tamaño y ubicación en el panel desempeña un papel de capital importancia, a ello hay que sumarle que es el único antropomorfo de brazos en asa con piernas que aparece en el conjunto de las ocho cavidades.

\subsection{Bacinete IV}

Bacinete IV está localizado en la concavidad opuesta a Bacinete VIII, se halla por tanto en el mismo bloque prismático pero en su lado norte.

De un total de treinta y seis figuras, se vislumbran dos combinaciones de elementos formadas por trazos rectos no identificables, puntuaciones, y restos de posibles puntuaciones:

1. P: Puntos.

2. NI: Figuras no identificables.

3. R: Restos.

\begin{tabular}{|c|c|c|}
\hline $\mathbf{P}$ & $\mathbf{N I}$ & $\mathbf{R}$ \\
\hline 33 & 2 & 1 \\
\hline $91 \%$ & $6 \%$ & $3 \%$ \\
\hline
\end{tabular}


Las puntuaciones son por tanto el motivo preponderante en Bacinete IV, incluso lo que se ha calificado como restos pudiera tratarse de una pequeña alineación de puntos. Todos ellos aparecen en alineaciones dobles, salvo en el caso de los posibles restos de puntuaciones, que en caso de tratarse efectivamente de puntos, sería una alineación simple. El resto son combinaciones de elementos no identificables a partir de trazos rectos.

Por tanto la abstracción y el esquematismo son la nota característica de Bacinete IV, no se ha hallado ningún motivo de temática o tendencia estilística naturalista.

\subsection{Bacinete $V$}

La cavidad que se ha denominado Bacinete $V$ es por soporte y tipología la más original de todos los lugares que componen el conjunto rupestre. En primer lugar, el tipo de soporte, una pequeña cueva formada por el desplome de un bloque de arenisca sobre otro, mientras que el resto de las cavidades son bloques prismáticos al aire libre con superficies cóncavas sobre las que se ejecutaron los motivos a los que la luz solar llega sin problema. En el caso de Bacinete $V$ esta condición no se cumple, la oscuridad es casi absoluta y los motivos que contiene no pueden ser vistos si el lugar no es iluminado artificialmente.

De nuevo estamos ante una cavidad con una ausencia total de figuras de tendencia naturalista. Pero curiosamente, se trata de la única en que aparecen puntos sin que éste motivo sea el más numeroso.

Se han descrito al menos diecisiete motivos entre los que se distinguen las siguientes tipologías:

1. A: Antropomorfos.

2. P: Puntos.

3. TR: Trazos rectos.

4. TCUI: Trazos curvos en U invertida.

5. R: Restos.

\begin{tabular}{|c|c|c|c|c|}
\hline $\mathbf{A}$ & $\mathbf{P}$ & TR & TCUI & $\mathbf{R}$ \\
\hline 7 & 3 & 2 & 1 & 3 \\
\hline $43,75 \%$ & $18,75 \%$ & $12,50 \%$ & $6,25 \%$ & $18,75 \%$ \\
\hline
\end{tabular}

La mayor parte de los motivos en Bacinete $\mathrm{V}$ son variantes de la figura tipo phi griega, sólo que sometiéndola a variaciones, en unos casos se omiten elementos, en otros se añaden. De lo que se deduce que seguramente estemos ante representaciones de antropomorfos. 


\section{Estructuras iconográficas apartir de modelo phi en Baciente $V$.}

Tipologia en tres cuartos de phi. (Casi se trata
de un ancoriforme). Motivo de Bacinete V.

Fig. 25. Tipologías de antropomorfos a partir del modelo en phi en Bacinete V.

Como se puede apreciar en la ilustración 25 , se ve claramente la evolución formal a partir de la tipología en phi griega. Posiblemente en un único motivo está representando más de un individuo. En otros casos dos motivos estarían en estrecha relación, el significado de estos va a estar condicionado por la misma, interaccionándose, no teniendo sentido el análisis de los mismos aisladamente. Relaciones de motivos que a pesar de estar compuestos por dos formas separadas, la ubicación en el abrigo y la posición simétrica entre sí subordina su significado a la interacción entre ambas, no siendo posible una interpretación válida de su análisis por separado. En Bacinete $V$ se llegan a relacionar hasta tres motivos, todos ellos variantes del tipo phi griega, buscando un concepto único (Ver figura 26).
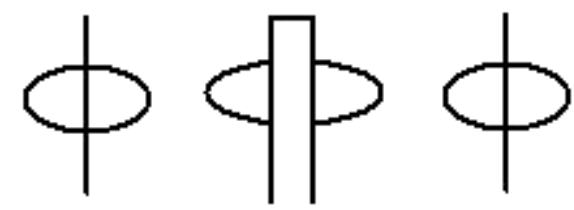

Fig. 26. Bacinete V. Motivos relacionados. 
Puesto que se ha interpretado la figura tipo phi griega como un antropomorfo con brazos en asa, parece probable que tanto las figuras que representan más de un antropomorfo como las relaciones entre figuras estén ilustrando algún tipo de relación entre individuos, familiares, sociales o de poder.

Este tipo de relaciones no son extrañas dentro del arte esquemático, ya Góngora y Martínez, en la Cueva de Los Letreros (Almería), documentó un supuesto árbol genealógico, que más tarde ratificaría Julián Martínez, aunque en este caso compuesto por antropomorfos bitriangulares.

También existen ejemplos de figuras compuestas a partir del modelo phi griega, como las que documentó Carrasco Rus en la Cueva Secreta o el Abrigo de la Higuera, ambos en la provincia de Jaén ${ }^{11}$.

En este caso son los antropomorfos la tipología preponderante, hay que destacar que todos ellos son antropomorfos basados en una tipología de trazo recto con brazos en asa o phi, pero algunos son medias phi, en otros casos, una phi simple y, a veces, una phi con más de un trazo recto vertical, es decir, una única figura puede representar varios antropomorfos.

Se distinguen los siguientes subtipos de antropomorfos:

1. A.PHI: Antropomorfo tipo $p h i^{12}$.

2. A.1/2PHI: Antropomorfo tipo media $p h i^{13}$.

3. A.3/4PHI: Antrpomorfo en $3 / 4$ de $p h i^{14}$.

4. A.2.PHI: 2 Antropomorfos tipo $p h i^{15}$.

5. A.3.PHI: 3 Antropomorfos tipo $p h i^{16}$.

\begin{tabular}{|c|c|c|c|c|}
\hline A.PHI & A.1/2PHI & A.3/4PHI & A.2.PHI & A.3.PHI \\
\hline 2 & 2 & 1 & 1 & 1 \\
\hline $28,57 \%$ & $28,57 \%$ & $14,28 \%$ & $14,28 \%$ & $14,28 \%$ \\
\hline
\end{tabular}

11 Carrasco Rus y otros, 1985.

12 El antropomorfo se forma a partir de un trazo recto vertical del que parten a izquierda y derecha sendos trazos curvos en asa a modo de brazos, el aspecto de esos motivos es muy similar a la letra griega phi, de ahí su denominación. En esta estadística se ha incluido una figura, que H. Breuil calcó completa y que hoy solo se ve como media phi. Se ha respetado el trabajo precedente, ya que es evidente la falta del soporte adyacente a esta figura.

${ }_{13}$ Se ha denominado como antropomorfo tipo media phi, aquellos que están formados por un trazo recto vertical y un único brazo en asa.

${ }_{14}$ Aquellos que no llegan a formar la típica figura en phi, debido a que a uno de los brazos en asa le falta un fragmento del arco del brazo.

${ }_{15}$ Este tipo trata de plasmar dos individuos o antropomorfos mediante una única figura, para ello se colocan, en vez de un trazo vertical, como se haría en la típica figura en phi, dos, pero la figura sigue contando con sólo dos trazos en asa.

16 En este caso el motivo cuenta con tres trazos verticales, por tanto, se trataría de tres antropomorfos. 
Tomando estos datos, a partir de siete motivos se contabilizarían diez antropomorfos. Es decir, en dos motivos se concentrarían el $50 \%$ de los antropomorfos de Bacinete $\mathrm{V}^{17}$.

De estos datos se puede concluir que el concepto antropomorfo representa un papel preponderante en Bacinete $\mathrm{V}$, en ninguna de las cavidades objeto de este trabajo va a tener la importancia que aquí detenta.

La relación espacial de los motivos es otra de las originalidades de esta cavidad con respecto al resto. En muchos casos se buscan distribuciones simétricas, por ejemplo, dos medias phi simétricas, o dos trazos rectos en paralelo. Sólo dos figura se encuentra aisladas, es decir no se encuentra en relación con otro motivo, esto supone el $12,50 \%$ de los motivos de la cavidad, incluso en este caso el aislamiento es relativo, puesto que uno de los motivos se trata de una figura en la que se plasman tres antropomorfos mediante tres trazos verticales paralelos unidos por dos trazos curvos que parten simétricos a modo de asas, se trata de la tipología que se ha denominado A.3:PHI.

Como es característico, en las cavidades menores del Conjunto rupestre de Bacinete, la clasificación estilística de la totalidad de los motivos es esquemática.

\subsection{Bacinete VI}

Bacinete VI es después de Bacinete VIII o Gran Abrigo la cavidad que cuenta con mayor número de motivos, aún a pesar de que una tupida pátina negra ocupa buena parte de la superficie decorada que a buen seguro ha destruido parte de los motivos realizados en origen. A parte de las representaciones contabilizadas y descritas, en Bacinete $\mathrm{VI}$ se observa una gran profusión de restos, que en este caso por su enorme cantidad y pequeño tamaño ha sido imposible contabilizar, pero que es importante tener en cuenta, hay que destacar además el gran número de oxidaciones naturales del soporte.

De nuevo, hay que destacar la ausencia de figuras de tendencia naturalista, por tanto la totalidad de los motivos se clasifican dentro de una secuencia esquemática. De un total de 110 motivos contabilizados se han obtenido las siguientes tipologías:

1. A: Antropomorfos.

2. P: Puntos.

\begin{tabular}{|c|c|}
\hline $\mathbf{A}$ & $\mathbf{P}$ \\
\hline 1 & 109 \\
\hline $1 \%$ & $99 \%$ \\
\hline
\end{tabular}

17 En esta estadística no se han reflejado los trazos rectos ni los curvos en $U$ invertida, en este sentido a pesar de que también pudieran tratarse de representaciones de individuos, pero esta posibilidad se mueve más en el terreno de la hipótesis, por ello se ha preferido no incluirlos y citarlos de un modo meramente descriptivo sin connotaciones subjetivas con vistas interpretativas. 
A pesar del abundante número de motivos, sólo se han encontrado dos tipologías: puntos y antropomorfos. El antropomorfo supone algo menos de un $1 \%$ del total. A pesar de ser tan insignificante su valor porcentual se trata de la figura de mayor tamaño, adquiere una importancia relevante teniendo en cuenta de que se trata del único antropomorfo itifálico de todo el Conjunto rupestre de Bacinete y que además es sin duda la figura más dinámica ya que está representada en clara actitud de movimiento.

Aunque la importancia del antropomorfo es clara, es imposible obviar la preponderancia que adquiere aquí el punto, sin duda es el lugar en el que resulta más representativo. Aparece siempre en relación a otros puntos. Se van a dar dos tipos de asociaciones, las alineaciones casi siempre dobles, y las asociaciones irregulares. De un total de ciento nueve puntos la proporción de asociación sería la siguiente:

1. P.AL: Puntos en asociación lineal.

2. P.Al: Puntos en asociación irregular.

\begin{tabular}{|c|c|}
\hline P.AL & P.Al \\
\hline 93 & 16 \\
\hline $85 \%$ & $15 \%$ \\
\hline
\end{tabular}

La lectura es clara y es la importancia preponderante de la asociación lineal de puntos. Dentro de la asociación lineal de puntos, en la que se encuentran afectados noventa y tres puntos, hay dos subtipos:

1. P.AL.S: Puntos en asociación lineal simple.

2. P.AL.2: Puntos en asociación lineal doble.

\begin{tabular}{|c|c|}
\hline P.AL.S & P.AL.2 \\
\hline 4 & 89 \\
\hline $4 \%$ & $96 \%$ \\
\hline
\end{tabular}

Los valores estadísticos son claros a este respecto, la asociación lineal doble es la más significativa en Bacinete VI, característica que también era preponderante en Bacinete IV, abrigo en el que también el punto era el motivo numéricamente más significativo. 


\subsection{Bacinete VII}

La cavidad que se ha denominado Bacinete VII se encontraba inédita, ya que fue el equipo que realizó el trabajo de campo él que lo descubrió y dio a conocer $^{18}$. Por tanto no aparece en publicaciones precedentes.

En dicha cavidad se localizó un único motivo en tinta roja. Parte de la figura se ha perdido, lo que impide dar una interpretación tipológica clara. Es probable que nos encontremos ante un antropomorfo esquemático, pero por precaución se ha preferido determinar como motivo no identificable. Hay que destacar de nuevo, la ausencia de elementos de tendencia naturalista, y que esta cavidad es junto a Bacinete I, la única que sólo contienen un motivo.

\subsection{Bacinete VIII o Gran Abrigo}

Bacinete VIII o Gran Abrigo es sin duda el lugar más conocido y representativo de todo el conjunto rupestre. Es el que más representaciones figuradas tiene y el único de todo el conjunto que cuenta con motivos de tendencia naturalista.

Las ciento sesenta y cuatro figuras totalizadas se han clasificado en nueve tipologías:

1. A: Antropomorfos.

2. Z: Zoomorfos.

3. P: Puntos.

4. PCT: Pectiniformes.

5. TR: Trazos rectos

6. CRU: Cruciformes

7. CUA: Cuadrangulares

8. NI: No identificables (se incluyen aquellas que se han considerado dudosas).

9. R: Restos.

\begin{tabular}{|c|c|c|c|c|c|c|c|c|}
\hline $\mathbf{A}$ & $\mathbf{Z}$ & $\mathbf{P}$ & PCT & TR & CRU & CUA & NI & R \\
\hline 26 & 16 & 60 & 1 & 8 & 4 & 2 & 12 & 35 \\
\hline $15,85 \%$ & $9,75 \%$ & $36,58 \%$ & $0.60 \%$ & $4,57 \%$ & $2,43 \%$ & $1,21 \%$ & $7,31 \%$ & $21,31 \%$ \\
\hline
\end{tabular}

18 Mas Cornellá, 1990. 
Por tanto, sumando antropomorfos y zoomorfos tendríamos el total de las figuras identificables con modelos reales para el espectador actual o de temática naturalista, de la suma del resto obtendríamos el total de representaciones a las que no encontramos parangones afines a la realidad o abstractas. La proporción sería la siguiente:

\begin{tabular}{|c|c|}
\hline $\mathbf{A}+\mathbf{Z}$ & P+NI+R+TR+CRU+CUA+PCT \\
\hline 42 & 122 \\
\hline $26 \%$ & $74 \%$ \\
\hline
\end{tabular}

Este dato es mucho más relevante de lo que en un principio pudiera parecer, ya que sólo un $24 \%$ de las figuras resultan identificables con modelos reales o son de temática naturalista. Una inspección visual apresurada en Bacinete VIII puede inducir a error, ya que la rápida localización por parte del espectador de los cérvidos puede inducir a interpretarla como una cavidad enmarcada dentro del estilo esquemático pero en la que los motivos de tendencia naturalista representan un papel preponderante. Por otra parte, en una primera aproximación, da la sensación de que la mayor parte de sus imágenes tanto esquemáticas como de tendencia naturalista son representaciones de temática naturalista. Esta impresión, como se ha demostrado después de un análisis detallado, es totalmente errónea, al menos numéricamente. Bacinete VIII es un abrigo en el que porcentualmente son significativamente más representativos los elementos abstractos o no identificables. Esta interpretación errónea se debe a que la mayor parte de los motivos identificables se encuentran concentrados en la parte izquierda del abrigo, discurriendo en progresiva disminución según se desarrolla el panel hacia la derecha. Dado que el sistema de lectura occidental es precisamente de izquierda a derecha, esta discriminación cerebral es lógica. A ello se le debe unir el hecho de que las figuras denominadas identificables o de temática naturalista son generalmente de mayor tamaño. Por otro lado, la parte central del panel, donde se amalgama un importante número de motivos, conserva mayor grado de saturación en el pigmento, resultando más llamativa al espectador.

Entre las representaciones denominadas identificables o de temática naturalista es donde se puede observar las variaciones de estilo; figuras de tendencia naturalista frente a figuras esquemáticas. Esta estadística por tanto se ha extraído de la suma de antropomorfos y zoomorfos, es decir de un total de cuarenta y dos representaciones.

\begin{tabular}{|c|c|}
\hline NATURALISTAS & ESQUEMÁTICAS \\
\hline \hline 12 & 30 \\
\hline $28,57 \%$ & $71,42 \%$ \\
\hline
\end{tabular}




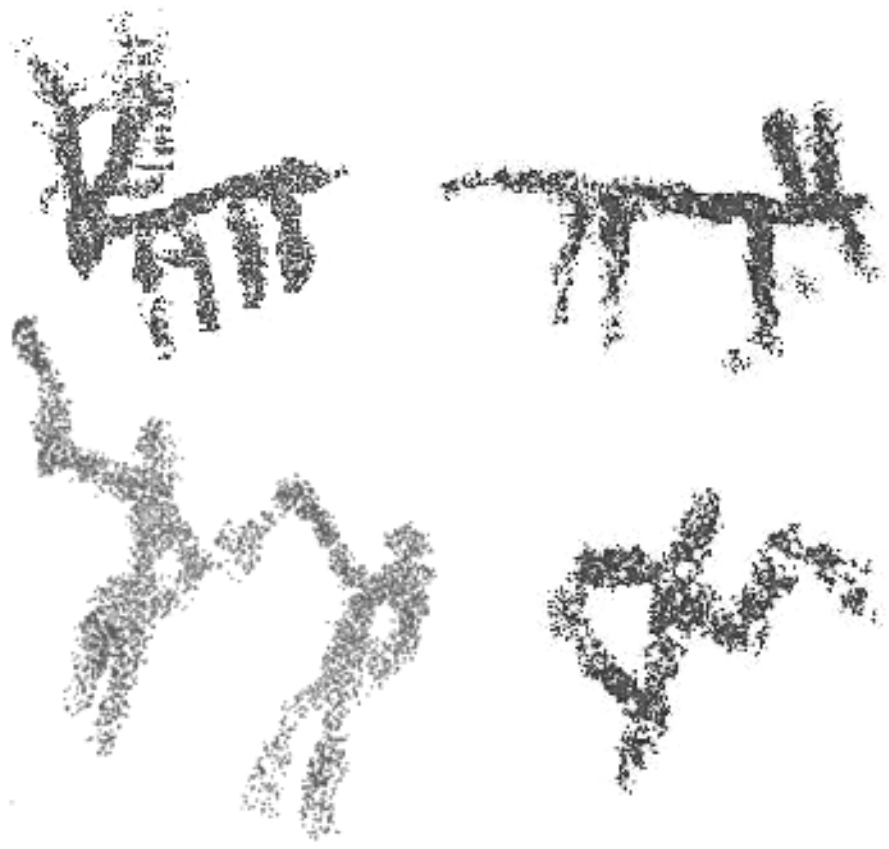

Fig. 27. Antropomorfos y zoomorfos de tendencia naturalista y esquemáticos en Bacinete VIII o Gran Abrigo.

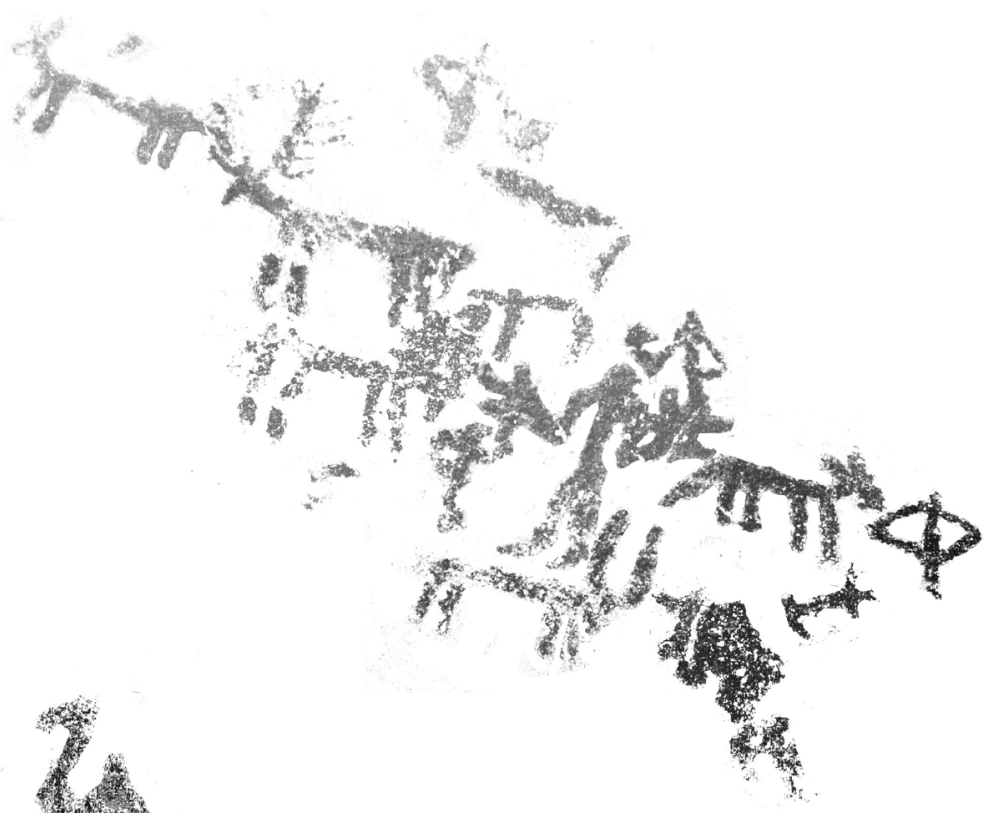

Fig. 28. Reproducción digital del fragmento del panel central de Bacinete VIII o Gran Abrigo. 
Los motivos estilísticamente esquemáticos priman sobre los motivos de tendencia naturalista, si a ello le sumamos los motivos no identificados o abstractos (entre los que destacan las combinaciones de elementos, trazos rectos, etc.) y las puntuaciones, se puede concluir que la secuencia estilística dominante en Bacinete VIII es la esquemática.

De nuevo, las estadísticas vuelven a contradecir lo que en una primera aproximación podría parecer. Aludíamos antes a que Bacinete VIII es mucho más abstracto de lo que una inspección visual apresurada podría indicarnos, algo parecido ocurre a la hora de abordar las matizaciones estilísticas, en un primer momento se percibe una gran importancia de los motivos de tendencia naturalista, que como se ha visto las estadísticas desdicen. Hay que resaltar nuevamente la mayor concentración de este tipo de motivos hacia la izquierda, el mayor tamaño de las mismas y en algunos casos, la mejor conservación de la saturación del pigmento. A esto habría que añadir otra explicación, que aunque obvia, no menos importante y es el hecho de que las representaciones de tendencia naturalista resultan más atractivas y llamativas por su belleza o por su fácil identificación con elementos reales. Llaman la atención sobremanera los cérvidos machos, se podría pensar que los zoomorfos son más representativos y sin embargo son más importantes en número los antropomorfos, tanto si se contabilizan globalmente (naturalistas y esquemáticos), como por separado.

La orientación de las figuras identificables tiene tres variantes, derecha, izquierda o frontal. La proporción entre un total de cuarenta y dos representaciones sería la siguiente:

\begin{tabular}{|c|c|c|}
\hline IZQUIERDA & DERECHA & FRONTAL \\
\hline 9 & 10 & 23 \\
\hline $21,40 \%$ & $23,80 \%$ & $54,76 \%$ \\
\hline
\end{tabular}

La orientación frontal es la dominante en más de la mitad, esto es debido a la preponderaría de los antropomorfos ya que todos los motivos orientados frontalmente son antropomorfos esquemáticos.

Hay que destacar también que los motivos orientados hacia la derecha cuentan con una proporción mayor frente a los orientados hacia la izquierda. No hay que pasar por alto el hecho de que todos los motivos orientados hacia la derecha son zoomorfos.

Los antropomorfos constituyen el $15,85 \%$ del total de las representaciones de Bacinete VIII, se han contabilizado veintiséis, es el tercer motivo en importancia y el primero dentro de las denominadas representaciones identificables o de temática naturalista. 
En cuanto a la variabilidad de estilo; antropomorfos de tendencia naturalista y antropomorfos esquemáticos, de un total de veintiséis la proporción sería la siguiente:

\begin{tabular}{|c|c|}
\hline Antropomorfos naturalistas & Antropomorfos esquemáticos \\
\hline 8 & 18 \\
\hline $30,76 \%$ & $69,24 \%$ \\
\hline
\end{tabular}

Es preponderante estilísticamente la secuencia esquemática también en los antropomorfos. Atendiendo a la orientación los datos obtenidos serían los siguientes:

\begin{tabular}{|c|c|c|}
\hline IZQUIERDA & DERECHA & FRONTAL \\
\hline 3 & 0 & 23 \\
\hline $11,53 \%$ & $0 \%$ & $88,47 \%$ \\
\hline
\end{tabular}

Hay que destacar que los tres antropomorfos que están orientados hacia la izquierda son de tendencia naturalista. Por tanto el $100 \%$ de los antropomorfos esquemáticos tienen una posición frontal. Todos los motivos con orientación frontal en Bacinete VIII son antropomorfos, de ellos diecinueve son esquemáticos y cuatro de tendencia naturalista.

En los antropomorfos del Bacinete VIII se presenta una singularidad y es que muchos de ellos portan objetos (útiles o instrumentos). De un total de veintisiete la proporción sería la siguiente:

1. A.CON: Antropomorfos con elementos complementarios.

2. A.SIN: Antropomorfos sin elementos complementarios.

\begin{tabular}{|c|c|}
\hline A.CON & A.SIN \\
\hline 15 & 11 \\
\hline $57,69 \%$ & $42,31 \%$ \\
\hline
\end{tabular}

Más de la mitad de los antropomorfos portan objetos, útiles o instrumentos, por tanto la relevancia de los mismos es capital. 
Dentro de los antropomorfos que portan objetos, útiles o instrumentos, varía la posición de los mismos, brazo derecho, izquierdo o ambos. De un total de quince que portan este tipo de elementos, la proporción en la ubicación del mismo sería la siguiente.

\begin{tabular}{|c|c|c|}
\hline IZQUIERDA & DERECHA & AMBAS \\
\hline 7 & 7 & 1 \\
\hline $46,66 \%$ & $46.66 \%$ & $6,66 \%$ \\
\hline
\end{tabular}

Se han observado al menos tres tipologías de objetos, útiles o instrumentos, los hay alargados, con una forma más redondeada y curvos.

De un total de dieciséis representaciones que se combinan con elementos complementarios la proporción considerando la tipología es la siguiente:

1. A.T.AL: Antropomorfos que portan elementos de tipología alargada.

2. A.T.RD: Antropomorfos que portan elementos de tipología redondeada.

3. A.T.AL+RD: Antropomorfos que portan elementos de tipología alargada y redondeada.

4. A.T.AR: Antropomorfos que portan elementos de tipología curva o en forma de arco.

\begin{tabular}{|c|c|c|c|}
\hline A.T.AL & A.T.RD & A.T.AL+RD & A.T.AR \\
\hline 8 & 4 & 1 & 2 \\
\hline $53,33 \%$ & $26,66 \%$ & $6,66 \%$ & $13,33 \%$ \\
\hline
\end{tabular}

La tipología alargada es la preponderante, hay que destacar que las tipologías alargada y redondeada aparecen tanto en antropomorfos de tendencia naturalista como esquemáticos. El único antropomorfo que presenta las dos tipologías pertenece a la secuencia esquemática. La última tipología, la curvada o en forma de arco, sólo aparece en dos antropomorfos y ambos estarían circunscritos estilísticamente a la secuencia esquemática.

Entre los diecinueve antropomorfos esquemáticos, se han observado diferentes tipologías; esquema tipo phi griega, en forma de T, cruciforme, ancoriforme, y algunos que por su deterioro se hace complicada su clasificación tipológica. En cualquier caso hay que destacar que en número la tipología más importante en $\mathrm{Ba}$ cinete VIII dentro de los antropomorfos es la derivada a partir de las formas en phi griega. 
En cuanto a los zoomorfos, de un total de dieciséis, la proporción estilística naturalismo-esquematismo sería la siguiente:

\begin{tabular}{|c|c|}
\hline Zoomorfos naturalistas & Zoomorfos esquemáticos \\
\hline 4 & 12 \\
\hline $33,33 \%$ & $66,66 \%$ \\
\hline
\end{tabular}

Es en los zoomorfos donde la tendencia naturalista tiene mayor representatividad, aún con todo, es la orientación estilística esquemática la preponderante también para estos motivos.

En cuanto a la orientación de los zoomorfos, de un total de dieciséis sería:

\begin{tabular}{|c|c|c|}
\hline IZQUIERDA & DERECHA & FRONTAL \\
\hline 6 & 10 & 0 \\
\hline $38 \%$ & $56 \%$ & $0 \%$ \\
\hline
\end{tabular}

Debemos destacar que los zoomorfos no se representan desde un punto de vista frontal, dinámica que se repite en casi todas las fases del arte prehistórico. Dada la ausencia de la orientación frontal, la totalidad de los animales están representados de perfil.

Dentro de la tipología zoomorfa, en la que hemos encuadrado dieciséis figuras, el $93,75 \%$ se encuadrarían entre los cuadrúpedos.

La siguiente subdivisión correspondería a las diferentes especies identificadas y a ejemplares en los que dado su alto grado de esquematización no ha sido posible su identificación. Se han contabilizado aquí las figuras que se han descrito como posibles. De un total de dieciséis figuras las especies y proporción serían las siguientes:

1. CER.M: Cérvido macho.

2. CER.H: Cérvido hembra.

3. CAR: Carnívoro.

4. EQU: Équido.

5. BOV: Bóvido.

6. AVE: Ave.

7. NI: No identificado.

\begin{tabular}{|c|c|c|c|c|c|c|}
\hline CER.M & CER.H & CAR & BOV & EQU & AVE & NI \\
\hline \hline 5 & 4 & 1 & 1 & 1 & 1 & 4 \\
\hline $31,25 \%$ & $25 \%$ & $6,25 \%$ & $6,25 \%$ & $6,25 \%$ & $6,25 \%$ & $25 \%$ \\
\hline
\end{tabular}


Se observa un claro dominio de los herbívoros sobre los carnívoros, sumando cérvidos (machos y hembras), el posible bóvido y el posible équido, se obtendría una proporción de un $68,75 \%$ de herbívoros frente al total. Los carnívoros sólo suponen el $6,25 \%$, al igual que las aves. Pero la especie preponderante será los cérvidos, la suma de los cérvidos machos y los cérvidos hembras supone el 56,25\%. Los machos son sin duda la categoría más representativa de Bacinete VIII, ya que suponen $31,25 \%$ del total, porcentaje superior al de los no identificados.

Hay que resaltar que todos los zoomorfos que hemos incluido dentro los no identificados responden estilísticamente a modelos esquemáticos, de ahí la dificultad en su identificación.

Solo se han calificado como zoomorfos de tendencia naturalista cuatro figuras, de las que tres son cérvidos (dos machos y una hembra) y un posible équido.

En cuanto a las puntuaciones, se han contabilizado un total de cincuenta y siete, lo que supone el $36,58 \%$ del total de las representaciones de todo Bacinete VIII o Gran Abrigo, es por tanto el motivo más numeroso. Las formas de aparición de las mismas son:

1. P.AIS: Puntos aislados.

2. P.AGR.IRR: Puntos agrupados irregularmente.

3. P.AGR.LIN: Puntos agrupados en alineaciones.

\begin{tabular}{|c|c|c|}
\hline P.AIS & P.AGR.IRR & P.AGR.LIN \\
\hline 7 & 6 & 47 \\
\hline $11,66 \%$ & $10 \%$ & $78,33 \%$ \\
\hline
\end{tabular}

De ello se puede extraer la abrumadora relevancia de las puntuaciones agrupadas, el $88,33 \%$ de los puntos aparecen asociados a otros, no es significativa su aparición aislada. La agrupación preponderante es la lineal, por tanto no parece probable que las posibles interpretaciones de las puntuaciones en Bacinete VIII se deban encaminar a su estudio como motivo aislado, sino que su hipotético sentido esta determinado por su aparición asociada a otros puntos.

\subsection{Estadísticas generales}

Tras haber analizado de modo individual cada una de las cavidades que componen el conjunto rupestre de Bacinete, se han contabilizado un total de trescientos sesenta y seis motivos entre figuras, puntuaciones, elementos no identificables, manchas y restos. El reparto por abrigos es el siguiente: 
1. B1: Bacinete I.

2. B2: Bacinete II.

3. B3: Bacinete III.

4. B4: Bacinete IV.

5. B5: Bacinete V.

6. B6: Bacinete VI.

7. B7: Bacinete VII.

8. B8: Bacinete VIII o Gran Abrigo.

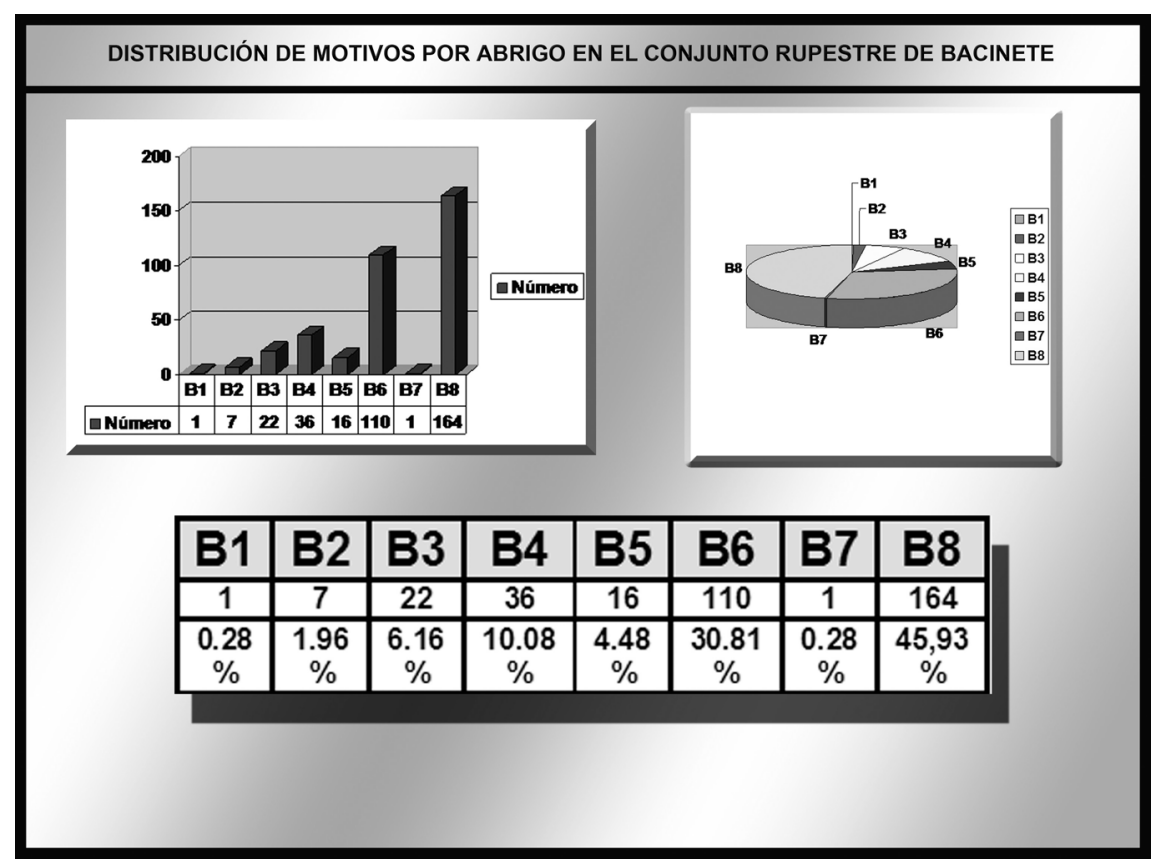

Fig. 29. Distribución de motivos por abrigos.

\begin{tabular}{|c|c|c|c|c|c|c|c|}
\hline B1 & B2 & B3 & B4 & B5 & B6 & B7 & B8 \\
\hline 1 & 7 & 22 & 36 & 16 & 110 & 1 & 164 \\
\hline $0.28 \%$ & $1.96 \%$ & $6.96 \%$ & $10.08 \%$ & $4.48 \%$ & $30.81 \%$ & $0.28 \%$ & $45.93 \%$ \\
\hline
\end{tabular}

Casi la mitad de las representaciones están concentradas en Bacinete VIII o Gran Abrigo. Sólo Bacinete VI posee un porcentaje superior al 10\%, que en este caso lo supera con creces gracias al gran número de puntuaciones. El resto de abrigos porcentualmente están por debajo del $11 \%$, sólo dos, Bacinete III y Bacinete IV, están por encima del $5 \%$, lo que quiere decir que hasta cuatro cavidades, Bacinete I, II, V y VII están por debajo del $5 \%$. De hecho la suma de éstos supone sólo un $7 \%$ de las representaciones de la totalidad del conjunto rupestre. 
Hay que destacar que Bacinete I, II, III, IV, V, VI y VII son enteramente esquemáticos, no existe en ellos ni un sólo motivo de tendencia naturalista. Bacinete VIII o Gran Abrigo es el único que cuenta con representaciones de tendencia naturalista, pero como se ha visto con anterioridad, ésta es en porcentaje significativamente inferior a la tendencia esquemática.

Bacinete VIII es la única cavidad que presenta representaciones zoomorfas. En las restantes cavidades las representaciones abstractas, puntuaciones y antropomorfos esquemáticos son las predominantes. Hay que señalar que en tres abrigos la representación antropomorfa juega un papel preponderante, unas veces por la situación del motivo en el panel, como es el caso de Bacinete III y VI y otras porque a la situación que ocupa en el soporte hay que unirle la importancia numérica en la cavidad, como es el caso de Bacinete $\mathrm{V}$, única cavidad en que los antropomorfos son dominantes frente al resto de motivos.

En cuanto a la orientación de los abrigos, destacaremos que predomina la orientación sur. Sólo Bacinete IV y V presentan una orientación norte. Si a ello unimos que Bacinete IV está ubicado en la concavidad opuesta del bloque en el que se encuentra Bacinete VIII y que Bacinete $\mathrm{V}$ es, como se ha visto, la única cavidad a la que no llega la luz solar a sus motivos, ya que la información que contiene parece estar dotada de una confidencialidad y especificidad ajenas al resto de las cavidades, se puede concluir que hay una especial preferencia por parte de los autores de las pinturas a la orientación sur. Posiblemente en Bacinete $V$ se valoró más la apariencia de caverna del lugar que la orientación, ya que en la zona inmediatamente aledaña no se observan cavidades semejantes.

Las tipologías del conjunto rupestre son las siguientes:

1. A: Antropomorfos.

2. Z: Zoomorfos.

3. PCT: Pectiniformes.

4. CUA: Cuadrangulares.

5. CRU: Cruciformes.

6. TR: Trazo recto.

7. TC: Trazo curvo.

8. P: Puntos.

9. R: Restos.

10. NI: No identificados.

\begin{tabular}{|c|c|c|c|c|c|c|c|c|c|}
\hline $\mathbf{A}$ & $\mathbf{Z}$ & PCT & TR & TC & CRU & CUA & P & NI & R \\
\hline 36 & 16 & 2 & 10 & 1 & 4 & 3 & 223 & 17 & 45 \\
\hline $10,08 \%$ & $4,48 \%$ & $0,56 \%$ & $2,80 \%$ & $0,28 \%$ & $1,12 \%$ & $0,84 \%$ & $62,46 \%$ & $4,76 \%$ & $12,61 \%$ \\
\hline
\end{tabular}


Como se puede deducir tras la observación de los datos anteriores, el motivo más numeroso es el punto, motivo que supone más de la mitad del total de las representaciones. El punto aparece en cinco de las ocho cavidades, Bacinete III, IV, V, VI y VIII. Salvo en Bacinete V, siempre que aparece este motivo es el más numeroso.

De la suma de antropomorfos más zoomorfos obtenemos el número de figuras identificables con elementos reales o de temática naturalista. Sumando el resto de los motivos obtendríamos el total de las representaciones no identificables con formas reales o representaciones abstractas.

1. $A+Z$ : Representaciones identificables con modelos reales.

2. $\mathrm{NI}+\mathrm{R}+\mathrm{P}+\mathrm{TR}+\mathrm{TC}+\mathrm{PCT}+\mathrm{CUA}+\mathrm{CRU}$ : Representaciones no identificables con modelos reales o abstractas.

\begin{tabular}{|c|c|}
\hline $\mathbf{A}+\mathbf{Z}$ & $\mathbf{N I + R + P + T R + T C + P C T + C U A + C R U}$ \\
\hline 52 & 305 \\
\hline $14,56 \%$ & $85,43 \%$ \\
\hline
\end{tabular}

La estadística con relación a esta cuestión resulta contundente, un 85,43\% de los motivos no son identificables con modelos reales, o dicho de otro modo, son de temática abstracta. En varias cavidades como Bacinete I, IV y VII no hay ni un solo motivo identificable o de temática naturalista. Bacinete VIII es el abrigo que cuenta con mayor número de motivos identificables o de temática naturalista.

De un total de cincuenta y dos motivos identificables con modelos reales o de temática naturalista, hay que distinguir entre dos tipos iconográficos, antropomorfos y zoomorfos. Hay que destacar que todos los zoomorfos se encuentran en Baciente VIII o Gran Abrigo de Bacinete.

Del total de cincuenta y dos motivos identificables con modelos reales o de temática naturalista, hay que distinguir entre los motivos estilísticamente de tendencia naturalista y los de tendencia esquemática.

De nuevo hay que resaltar, que todos los motivos estilísticamente naturalistas se localizan en el abrigo VIII.

\begin{tabular}{|c|c|}
\hline NATURALISMO & ESQUEMATISMO \\
\hline 12 & 40 \\
\hline $23,07 \%$ & $76,93 \%$ \\
\hline
\end{tabular}


En este punto la estadística vuelve a ser contundente, solo el $23,07 \%$ de los motivos se caracterizan por su tendencia naturalista. Esta conclusión era más que previsible después del análisis individual de los diferentes abrigos, ya que salvo Bacinete VIII, el resto de las cavidades son en su totalidad esquemáticas y en Bacinete VIII, a pesar de la presencia de motivos de tendencia naturalista, estadísticamente prevalece el esquematismo y la abstracción. Por tanto, una conclusión clara es que el conjunto rupestre de Bacinete es predominantemente esquemático.

\section{BACINETE. ESTADO ACTUAL DE CONSERVACIÓN}

\subsection{Degradación antrópica}

El conjunto rupestre de Bacinete, como se ha visto, constituye una de las estaciones de arte rupestre más importantes dentro de la secuencia esquemática. Una de sus excepcionalidades radica en el gran número de representaciones que se concentran en un único abrigo, como es el caso de Bacinete VIII o Gran Abrigo, sus ciento sesenta y cuatro representaciones, entre figuras, puntuaciones y restos suponen una rareza dentro del arte esquemático, ya que las cavidades características del estilo que se ha venido denominando como esquemáticas, suelen ser muy inferiores en número de motivos, limitándose a un pequeño repertorio de figuras aisladas.

En Bacinete se conjugan la excepcionalidad de estilo en Bacinete VIII o Gran Abrigo y la generalidad de los abrigos menores (Bacinete I, II, III, IV, V, VI y VII), que responden más a lo que viene siendo usual en las estaciones circunscritas en la secuencia esquemática.

Pero limitar la importancia de Bacinete a una mera cuestión estadística sería simplista, ya que algunos de sus motivos se han convertido en imágenes representativas en estudios y publicaciones que pretenden abordar el esquematismo, sirvan de ejemplo los antropomorfos de tendencia naturalista que portan objetos, útiles o instrumentos que desde que $\mathrm{H}$. Breuil publicara sus estudios, se han convertido en una imagen ampliamente conocida para los estudiosos del arte prehistórico. Por otra parte Bacinete $\mathrm{V}$ constituye un exponente atípico dentro de las manifestaciones circunscritas dentro del arte esquemático.

Como desgraciadamente viene siendo habitual en numerosos lugares que albergan manifestaciones rupestres prehistóricas, Bacinete lejos de ser un emplazamiento cuidado, se encuentra en un completo abandono, sufriendo una paulatina degeneración con el paso de los años.

Entre los años 1988 y 1993, cuando se realizaron los trabajos de campo, Bacinete se encontraba sin ningún tipo de protección. 
Las agresiones han sido frecuentes a lo largo de los años, el lugar es ampliamente conocido por las gentes del entorno, la consecuencia de esta popularidad es que Bacinete ha sufrido una gran variedad de atentados y actos vandálicos, valgan de ejemplo las pintadas o los destrozos debidos a los intentos para arrancar el propio soporte rocoso con intención de llevarse las pinturas. En este sentido es significativo el ejemplo de Bacinete $\mathrm{V}$, en el que parte del soporte ha sido levantado, perdiéndose irremediablemente la mitad de una de las figuras, motivo que anteriormente $\mathrm{H}$. Breuil pudo contemplar en su integridad.

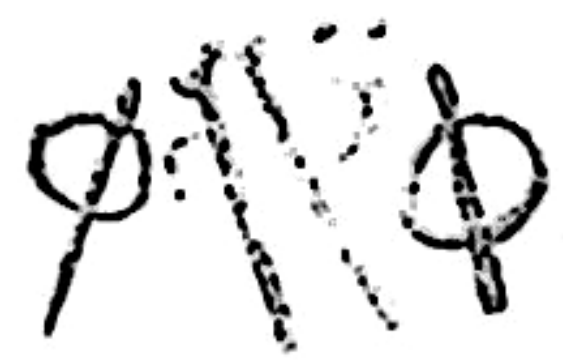

Fig. 30. Bacinete V. Composición según H. Breuil.

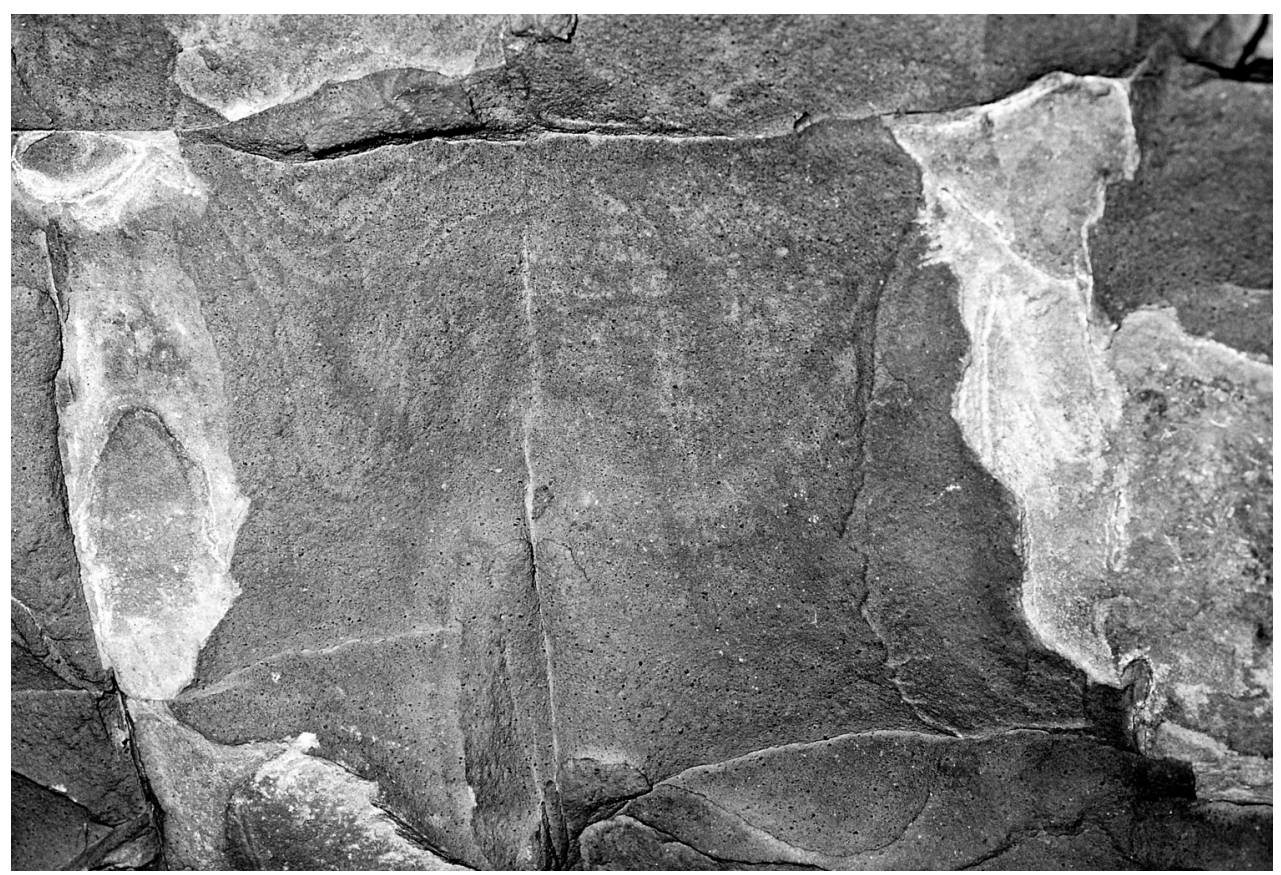

Fig. 31. Bacinete V. Estado actual de conservación de la composición. 


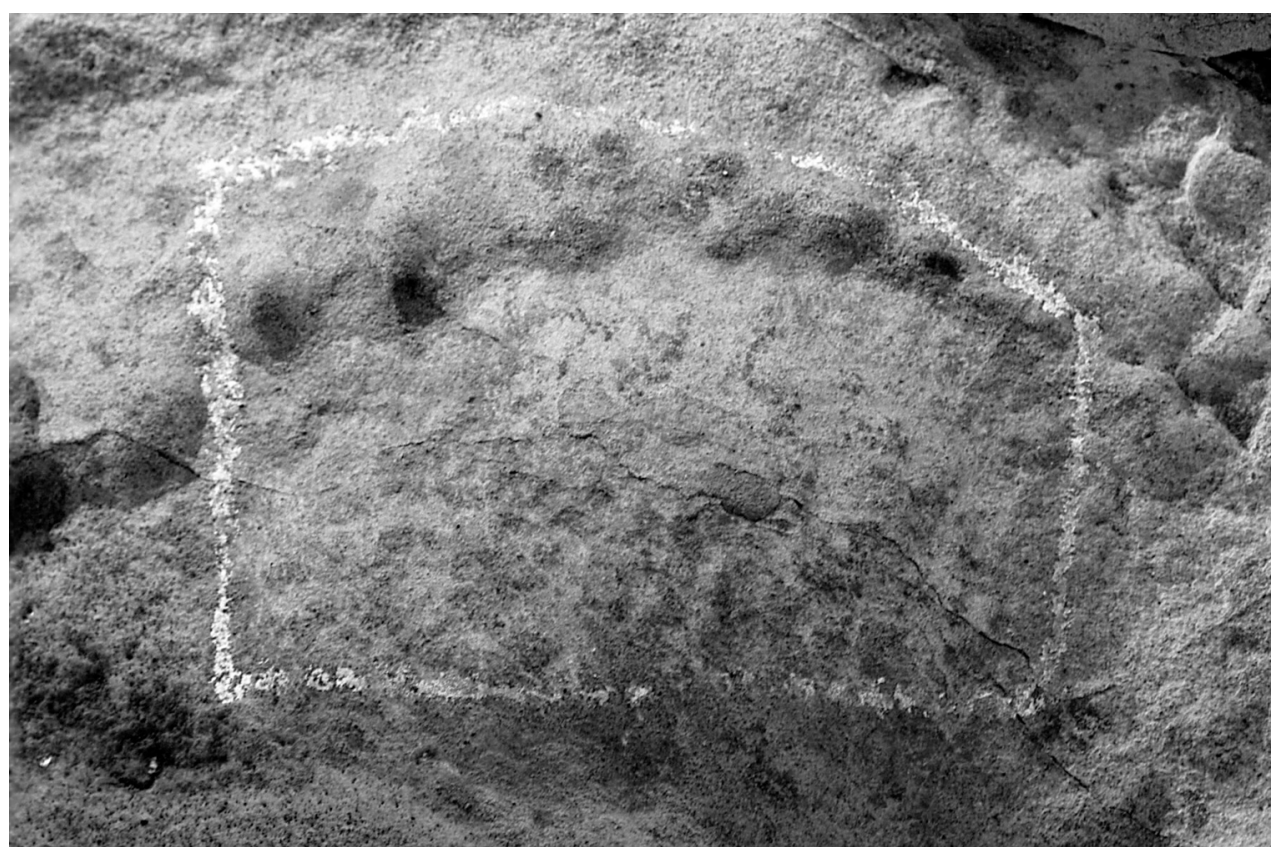

Fig. 32. Bacinete VIII o Gran Abrigo. Pintadas recientes.

Las pintadas y los grabados son otra de las variantes de las acciones vandálicas que han sufrido las cavidades.

Las repetidas barbaridades impulsaron a que algunas personas se plantearan la protección de Bacinete. En 1993 Lothar Bergmann emprende una cruzada para el cerramiento de abrigos decorados en la comarca del Campo de Gibraltar. El 24 de marzo de 1993, en una nota de prensa en el diario Europa Sur, se anuncia el cerramiento de los abrigos con arte rupestre emplazados en el Parque Natural de los Alcornocales y la Cueva de las Palomas por parte de la Consejería de Cultura de la Junta de Andalucía.

Lo que en un principio pareció la solución de los problemas de Bacinete, desgraciadamente se ha ido convirtiendo en un elemento más en la degradación progresiva de la estación rupestre.

La instalación de una reja, no sólo no ha supuesto el fin del vandalismo, sino que ésta constituye un reclamo, ya que la superación de la misma resulta fácil, y lo que en un paseo distraído es sólo un bloque de piedra, con la reja se convierte en un punto de atención para cualquier paseante que muchas veces ignora el valor de lo que allí se conserva.

Las proliferaciones arbustivas que crecen de manera natural impiden la óptima contemplación desde la reja, se aumenta así la posibilidad de una incursión in- 


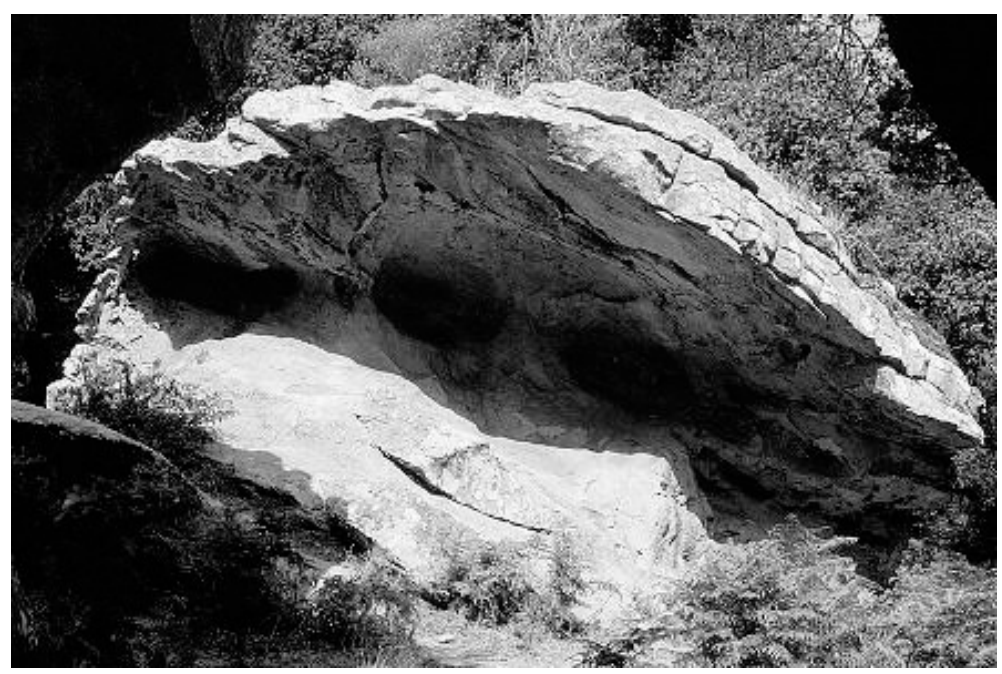

Fig. 33. Bacinete VIII o Gran Abrigo. Aspecto en 1990.

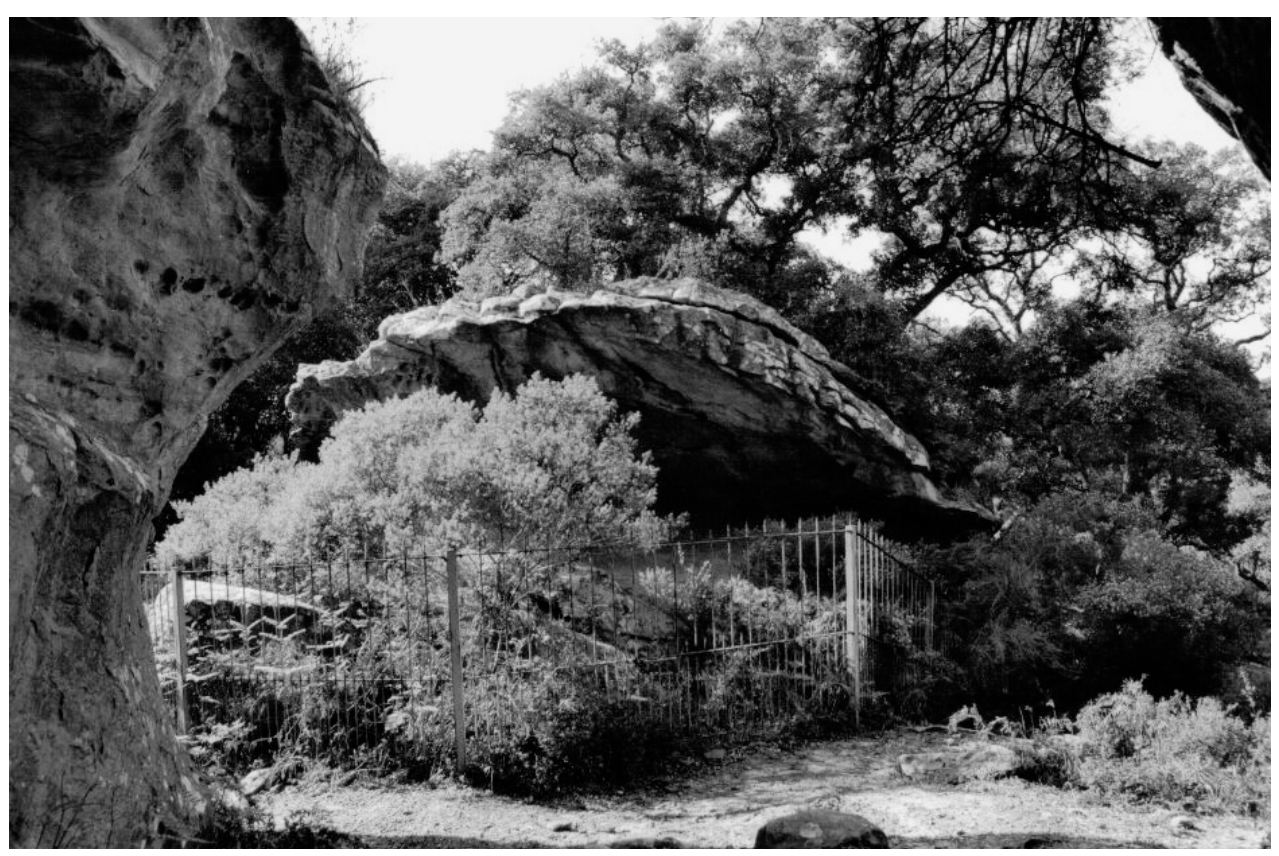

Fig. 34. Bacinete VIII o Gan Abrigo. Aspecto en abril de 2005.

controlada. Lo que en tiempos era un paraje de incomparable belleza, rodeado de helechos, se ha convertido en un lugar lleno de desperdicios. La reja se halla corroída por el óxido y el aspecto del lugar dista mucho de parecer un enclave artís- 
tico y arqueológico. El estudio, musealización y conservación de un entorno arqueológico es una cuestión compleja, hay que someterlo a un estudio preciso, porque lo que en un principio pretendía ser una protección ha demostrado ser un elemento que agrava los problemas. Basta comparar las imágenes del lugar con y sin la verja.

Las consecuencias de esta medida no tardarían en llegar, el día 1 de noviembre de 2002, aparecía una nota de prensa en el diario Europa Sur, «Dañan las pinturas de Bacinete». En el se relata, por este orden, como unos incontrolados habían dañado la verja y habían pintado sobre ellas con tizón negro.

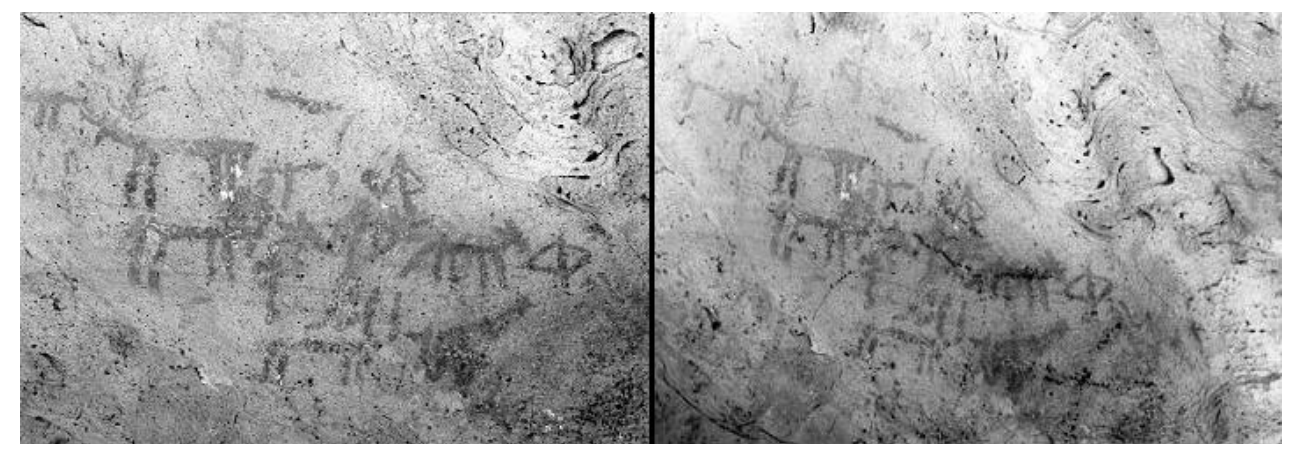

Fig. 35. Estado del panel antes y después de la incursión de incontrolados en 2002.

Lo que antes era un lugar accesible para los incontrolados que conocían el lugar, con la verja supone una llamada de atención para cualquier visitante que desconozca que en la zona se conservan vestigios de un pasado prehistórico, y desgraciadamente no todos están concienciados del valor de este patrimonio.

Pero, la variedad de tropelías no acaba con lo hasta ahora dicho, algunos visitantes deciden emular a sus antecesores prehistóricos y realizan motivos de nuevo cuño.

Debemos plantearnos una reflexión profunda a propósito de las intervenciones encaminadas a la protección y conservación, no sólo de Bacinete, sino del arte prehistórico en general, éstas han de llevarse a cabo después de un concienzudo estudio previo, valorando previamente los pros y contras de estas intervenciones. Para ello el dialogo interdisciplinar es de una valor inestimable, es imprescindible hacer un diagnóstico previo del posible impacto, en este caso de una verja o en otros de una limpieza o restauración.

A pesar de la Ley de Patrimonio Histórico Español que en 1985, en su artículo 40.2, declara Bien de Interés Cultural, garantizando su protección, cualquier lugar, sea de la índole que sea, siempre que mantenga algún vestigio de arte rupestre prehistórico y a que en 1998 el Comité de la UNESCO aprobó la Declaración de 
Patrimonio de la Humanidad para el Arte Rupestre del Arco Mediterráneo de la Península Ibérica, incluyendo setecientos cincuenta y siete estaciones parietales, comprendidas en siete comunidades autónomas, entre las que se incluye a Andalucía, Bacinete no está protegido ni incluido dentro de éstas. Esperemos que los estudios que se están realizando demuestren la trascendencia del lugar y sirva para concienciar a quien proceda de la necesidad de tomar medidas contrastadas para su conservación.

\subsection{Degradación natural}

Hasta ahora, hemos calibrado la degradación de Bacinete a partir de las intervenciones antrópicas. Pero hay que atender a otro tipo de degradaciones naturales, algunas veces desencadenadas por factores de tipo físico, la climatología por ejemplo. En esta zona el viento Levante es un factor a tener en cuenta en la erosión del soporte rocoso que alberga las pinturas.

En cuanto al estado de conservación de la roca soporte, brevemente nos referiremos al origen numídico de las areniscas. La tipología de la arenisca es silícea, propia de las llamadas Areniscas del Aljibe, presentan una morfología de tafonis, se forman así grandes bloques prismáticos. Los bloques presentan líneas de corrosión marcadas formando retículas ${ }^{19}$, determinadas por los planos de estratificación.

La roca soporte del conjunto presenta una corrosión preferente en la zona basal próxima al suelo, se forman así las superficies cóncavas en los abrigos. En la superficie se observan zonas en proceso de degradación por alteraciones químicas. Las tipologías de alteración van desde la formación de alvéolos por acción eólica al desarrollo de escamas a favor de los planos de laminación de las areniscas, pasando por la abrasión eólica y la alteración química.

Los aspectos meteóricos no sólo afectan al soporte, sino que de un modo directo afectan a la conservación de los pigmentos, a la espera de estudios más específicos que lo corroboren y atendiendo a la observación detallada de los motivos y su ubicación dentro de los abrigos, la sensación es que el tipo de pigmento es el mismo para todas las imágenes y para todos lo abrigos, a pesar de ello se observan matizaciones de color, más claro o más oscuro. La explicación de esta matización, tiene más que ver con un deterioro progresivo del pigmento, que con una intencionalidad por parte del autor o los autores de conseguir distintas tonalidades.

Se da la circunstancia de que las zonas más protegidas a los elementos meteorológicos (precipitaciones o viento) son las que se caracterizan por tener una coloración más oscura, mientras que en las zonas más expuestas el tipo de coloración es más claro, cuanto más se acentúa la desprotección ante los fenómenos

19 Mas Cornellà y otros, 1994. 
atmosféricos, más se acusa esta premisa, en algunos casos la imagen se ha desdibujado casi completamente, de hecho, algunas de ellas sólo se han podido contemplar íntegramente después del tratamiento digital. Por ello no es descartable que en origen el número de imágenes fuera superior al que se ha conservado hasta hoy.

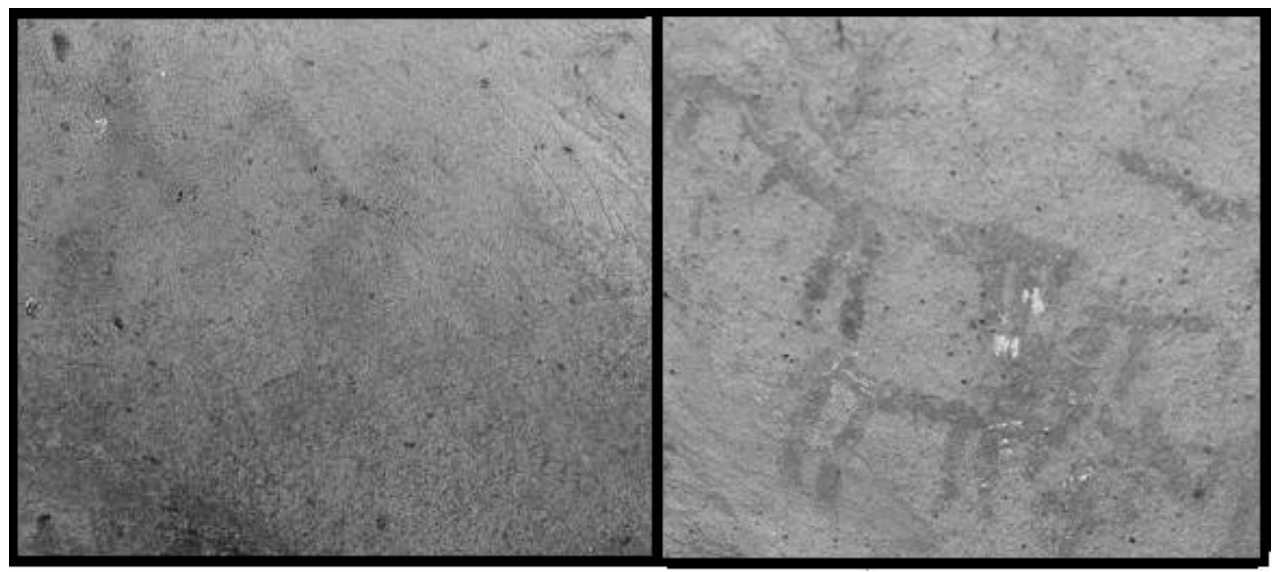

Fig. 36. Diferenciación de tonalidades en Bacinete VIII o Gran Abrigo.

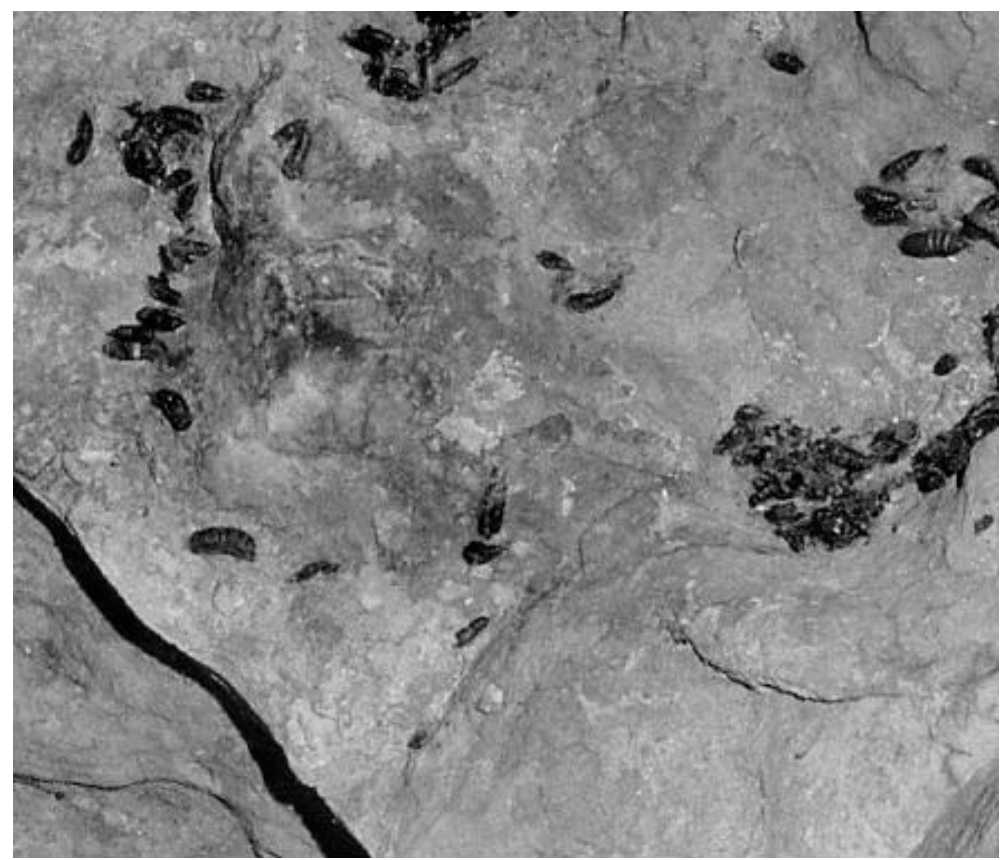

Fig. 37. Larvas de insectos adheridas en la superficie de Bacinete VIII o Gran Abrigo. 


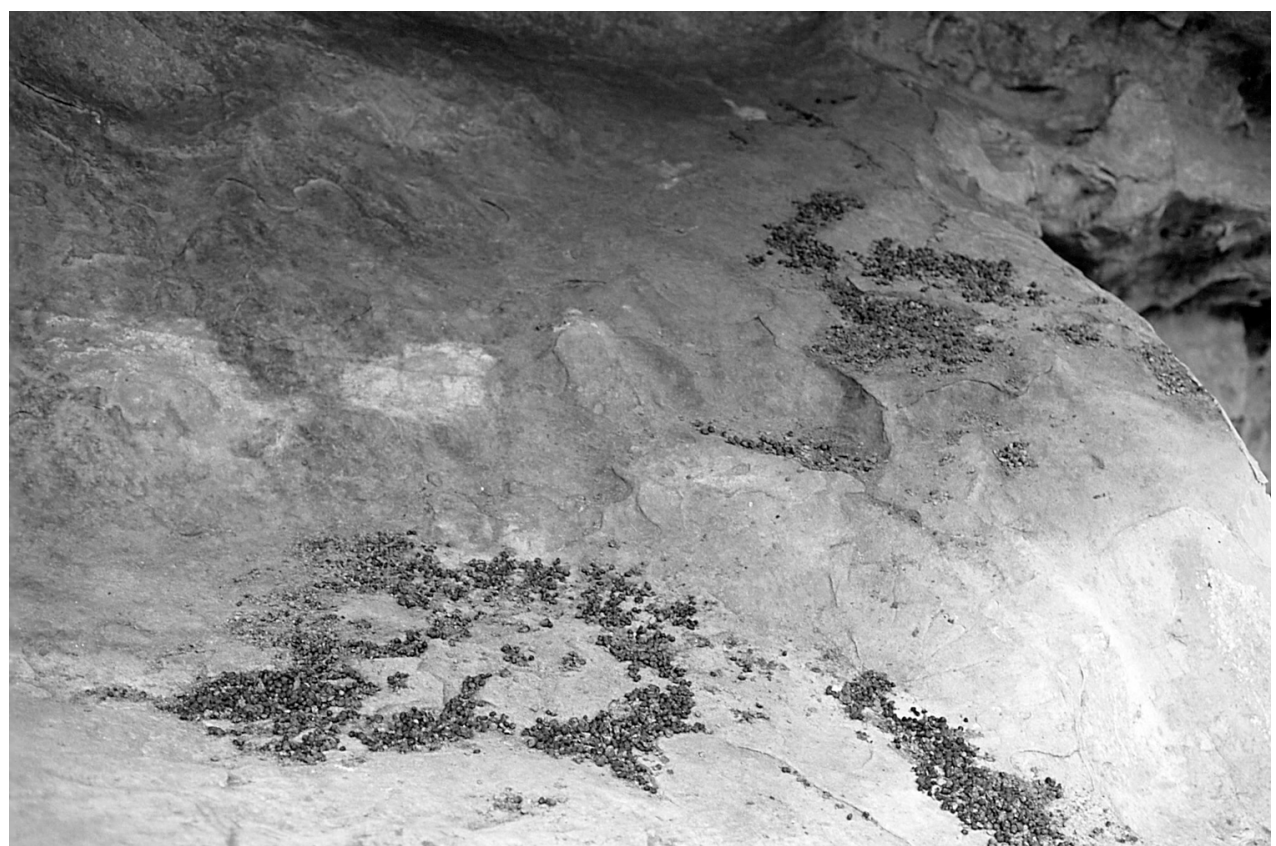

Fig. 38. Excrementos de animales en el suelo de Bacinete VIII o Gran Abrigo.

A parte de las degradaciones naturales aludidas, no hay que dejar de mencionar otras degradaciones también de origen natural, que nada tienen que ver con procesos atmosféricos, químicos o por la interacción del pigmento con el soporte, sino que es debida a elementos vivos, como la acción de organismos vegetales y animales.

En determinadas zonas la superficie de los bloques alberga multitud de líquenes, nidos de aves, larvas $u$ otras formaciones orgánicas generadas por insectos.

Afortunadamente no es importante la degradación debida a excrementos de aves, pero si se observa la ocupación ocasional de pequeños mamíferos, como roedores que dejan huellas de su paso en los suelos de los abrigos.

Otro tipo de degradación natural, debida a la acción de animales, es la ocasionada por la frotación de las cabras contra los paneles decorados ${ }^{20}$. En el caso de Bacinete VIII, este tipo de degradación es previa a la colocación de la reja, que afortunadamente sí es efectiva para evitar este fenómeno, el resto de los abrigos siguen hoy expuestos a este factor. La consecuencia de esta frotación produjo en su día la degradación y difuminación del pigmento de muchos motivos, tanto que en algunos casos se pierden en parte o totalmente.

20 Barroso Ruiz, 1991. 
En otros lugares, el pigmento no ha desaparecido, pero ha sufrido una alta difuminación, lo que en origen fueron figuras con contornos nítidos e identificables hoy son meras manchas o restos.

\section{BIBLIOGRAFÍA}

Acosta MartíneZ, P. (1965): «Significado de la pintura rupestre esquemática», Zephyrus, XVI.

- (1967): «Representaciones de ídolos en la pintura rupestre esquemática española», Trabajos de Prehistoria, XXIV.

Amitrano, Bruno (1985): «Evolución y desarrollo de los criterios de restauración de la antigüedad al panorama actual», Revista de Arqueología, 47.

Aparicio Pérez, J. y San Valero Aparisı, J. (1983): El primer arte valenciano. I. El arte Parpallonés, Asociación cultural Valenciana-2000, Valencia.

ARROYO DEL REY, María y otros (1997): «Materialidad de las obras de arte. Estudio mediante métodos científicos», Técnica y arte. DYNA, 6.

BÉCARes PÉREZ, J. (1983): «Hacia nuevas técnicas de trabajo en el estudio de la pintura rupestre esquemática», Actas del coloquio internacional sobre arte esquemático de la Península Ibérica, Zephyrus, XXXVI.

- (1974): Nuevas pinturas en Las Batuecas: El Covacho del Palló, Universidad de Salamanca.

- (1976): Pinturas del Corral de Morcilla (Las Batuecas), Universidad de Salamanca.

Beltrán Martínez, A. (1969): «Las pinturas esquemáticas de Olmetta du Cap (Córcega)», Monografías Arqueológicas, V.

- (1983): «El arte esquemático en la Península lbérica: Orígenes e interrelación. Bases para un debate», Actas del coloquio internacional sobre arte esquemático de la Península Ibérica, Zephyrus, $\mathrm{XXXVI.}$

BergmanN, Lothar (2003): Arte sureño. El arte rupestre del extremo sur de la Península lbérica, AGEDPA, Cádiz.

BreUIL, H. y BuRkItT, M.C. (1929): Rock paintings of Southern Andalusia. A description of a Neolithic and Copper Age art group, Clarendon Press, Oxford.

Barroso Ruiz, C. (1991): «Investigación en el conjunto rupestre de arte postpaleolítico de Bacinete. Los Barrios (Cádiz)», IV Jornadas de Arqueología Andaluza, Junta de Andalucía, Dirección General de Bienes Culturales, Sevilla.

CABRÉ AGuiló, J. (1915): El arte rupestre en España (regiones septentrional y oriental), Comisión de Investigaciones Paleontológicas y Prehistóricas, Madrid.

- y HeRnÁndez PACHeco, E. (1914): Avance al estudio de las pinturas prehistóricas del extremo sur de España (Laguna de la Janda), Comisión de Investigaciones Paleontológicas y Prehistóricas, Madrid.

Cabrera Orti, M. A. (1944): Los métodos de análisis fisico-químicos y la Historia del Arte, Universidad de Granada, Diputación Provincial de Granada.

Carrasco Rus, J., Carrasco Rus, E., Medina Casado, J. y Torrecillas Gonzales, J. F. (1985): El fenómeno rupestre esquemático en la cuenca alta del Guadalquivir. I: Las sierras Subbéticas, Amigos de la arqueología giennense (Prehistoria Giennense, 1).

Cano Herrera, M. y otros (1987): Prehistoria, Editorial Nájera, Madrid.

Castillo RequenA, J.M. (1993): El clima de Andalucía, Instituto de Estudios Almerienses.

COSTAS GoBERnÁ, J. (1995): La figura humana en los grabados rupestres prehistóricos del continente europeo, Asociación Arqueológica Viguesa.

- e HidALGo CuñARRo, J. M. (1996): Los motivos geométricos en los grabados rupestres prehístoricos del continente europeo, Asociación Arqueológica Viguesa.

- e HidAlgo CuñaRRo, J. M. (1997): Los motivos de fauna y armas en los grabados prehístóricos del continente europeo, Asociación Arqueológica Viguesa.

DíAz CASADO, Y. (1992): El arte rupestre esquemático en Cantabria: una revisión crítica, Universidad de Cantabria, Santander.

FATAS, G. y BoRRÁs, G. (1988): Diccionario de términos de arte y elementos de arqueología y numismática, Alianza Editorial, Madrid.

GIEDION, S. (1981): El presente eterno. Los comienzos del arte, Alianza Editorial, Madrid.

GómEZ BARRERA, J.A. (1982): La pintura rupestre esquemática en la altimeseta Soriana, Ayuntamiento de Soria, Comisión de Cultura. 
Gómez GonZÁlez, M. L. (1994): Examen científico aplicado a la conservación de obras de arte, Ministerio de Cultura, Madrid.

GutiérRez González, J. A. y Avelló Alvárez, J. L. (1986): Las pinturas rupestres esquemáticas de Sésamo, Vega de Espinareda (León), Centro de investigación y Museo de Altamira, Ministerio de Cultura, Santander.

Gutiérrez Mas, J. M, Martín Algarra, A., Domínguez Bella, S. y Moral Cardona, J. P. (1991): Introducción a la geología de la provincia de Cádiz, Servicio de Publicaciones de la Universidad de Cádiz.

GutiérRez Mas, J. M, Martín AlgarRa, A. y Salvador NavarRete, A. (1982): Itinerarios geológicos por la provincia de Cádiz, Servicio de Publicaciones de la Universidad de Cádiz.

Hernández Pérez, M., Ferrer i Marset, P. y Catalá Ferrer, E. (2000): L 'Art esquemàtic, Ayuntamiento de Cocentaina.

JORDÁ, F. (1966): Notas para una revisión del arte rupestre levantino, Universidad de Salamanca.

Lerol-Gourhan, A. (1968): Prehistoria del arte occidental, Gustavo Gili, Barcelona.

López Ontiveros, A. (2003): Geografía de Andalucía, Ariel, Madrid.

MACARRón Miguel, A. M. (1995): Historia de la conservación y la restauración, Tecnos, Madrid.

MAS CORNELLÀ, M. (1988): «Las manifestaciones rupestres prehistóricas de la zona gaditana. 1988: Sierra Momia", Anuario Arqueológico de Andalucía, 1988. Actividades sistemáticas, informes y memorias, Dirección General de Bienes Culturales de la Consejería de Cultura de la Junta de Andalucía, Sevilla.

- (1989): «Las manifestaciones rupestres prehistóricas de la zona gaditana. 1989: Sierra Momia y Valle del Río Cañas o Palmones», Anuario Arqueológico de Andalucía, 1989. Actividades sistemáticas, informes y memorias, Dirección General de Bienes Culturales de la Consejería de Cultura de la Junta de Andalucía, Sevilla.

- (1990): «Proyecto de investigación arqueológica. Las manifestaciones rupestres prehistóricas de la zona gaditana. 1990: Reproducción y estudio directo del arte rupestre en Sierra Momia y Valle del Río de las Cañas o Palmones», Anuario Arqueológico de Andalucía, 1990. Actividades sistemáticas, informes y memorias, Dirección General de Bienes Culturales de la Consejería de Cultura de la Junta de Andalucía, Sevilla.

- (1991): «Documentación e investigación de las manifestaciones artísticas en las cuevas de Palomas, abrigos de Bacinete y conjunto rupestre del Tajo de las Figuras (Cádiz)", Anuario Arqueológico de Andalucía, 1991. Actividades sistemáticas, informes y memorias, Dirección General de Bienes Culturales de la Consejería de Cultura de la Junta de Andalucía, Sevilla.

- (1992): «El arte prehistórico en las sierras del Campo de Gibraltar», Anuario Arqueológico de Andalucía, 1992. Actividades sistemáticas, informes y memorias, Dirección General de Bienes Culturales de la Consejería de Cultura de la Junta de Andalucía, Sevilla.

- (2000a): Proyecto de investigación arqueológica. Las manifestaciones rupestres prehistóricas en la zona gaditana, Consejería de Cultura de la Junta de Andalucía, Sevilla.

- (2000b): «De los cazadores recolectores del holoceno inicial a las sociedades productoras en Anda-

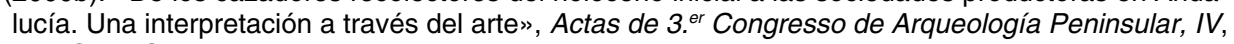
ADECAP, Oporto.

- (2001): «Estructuras iconográficas e identificación de especies (secuencias iniciales y finales del arte postpaleolítico «esquemático»)», Cuadernos de Prehistoria y Arqueología de Castelló, 22.

- (2005): La Cueva del Tajo de las Figuras, UNED, Madrid.

- y FINLAYSON, C. (2001): «La representación del movimiento y la actitud (antropomorfos y zoomorfos) en los motivos pictóricos de los abrigos rocosos de Sierra Momia (Benalup-Casas Viejas, Cádiz)", Espacio, tiempo y forma. Revista de la Facultad de Geografía e Historia de la UNED. 1, 14.

- JoRdÁ, J., CAMBRA, J., MAS, J. y LOMBARTE, A. (1994): «La conservación del arte rupestre en las sierras del Campo de Gibraltar. Un primer diagnóstico", Espacio, tiempo y forma. Revista de la Facultad de Geografía e Historia de la UNED. 1, 7.

Moure Romanillo, A. (1999): Arqueología del arte prehistórico en la Península lbérica, Síntesis, Madrid. - (1999): El origen del hombre, Historia 16, Madrid.

Pericot García, L. (1942): La cueva del Parpalló, Consejo Superior de Investigaciones Científicas, Valencia.

PIJOÁN, J. (1966): El arte prehistórico Europeo. Summa Artis. Historia General del Arte. VI, Espasa Calpe, Madrid.

RAmíREZ, F. y otros (1966): Introducción a los métodos de ensayos no destructivos, INTA, Madrid.

RENFREW, C y BAHN, P. (1993): Arqueología. Teoría, métodos y práctica, Akal, Madrid.

Ripoll Perelló, E. (1986): Orígenes y significado del arte Paleolítico, Sílex, Madrid.

- (2001): Prehistoria (Paleolítico y Mesolítico). I, UNED, Madrid. 
SANCHIDRIÁN TORTI, J. L. (2001): Manual de arte prehistórico, Ariel, Madrid.

SeRvicio Geográfico del EJérCito (1997): Mapa militar digital de España (en CD-Rom), Ministerio de Defensa, Ejercito de Tierra, Madrid.

- (1982): Hoja 1074-IV. Zanona. Tahivilla 1074, Escala 1:25.000, Mapa Topográfico Nacional, Instituto Geográfico Nacional, Madrid.

— (1987): Hoja 13-47 (1074). Tahivilla, Serie L, Escala 1:50.000, Cartografía Militar de España, Ministerio de Defensa, Madrid.

Solís DelGADo, M. (2004): «El Conjunto rupestre de Bacinete. Los Barrios. Una reflexión en torno al arte esquemático", Euphoros. Revista del Centro Asociado a la UNED del Campo de Gibraltar, 7.

- (2005): «El Conjunto rupestre de Bacinete (Sierra del Niño, Los Barrios, Cádiz)». Actas de las I Jornadas de Patrimonio en la Comarca del Guadalteba "Arte rupestre con expresiones gráficas», Ardales.

TECAL (1997): Ensayos no destructivos, técnicas radiológicas aplicadas a obras de arte, TECAL, Madrid. Vilanova y Piera, J. y De la Rada Delgado, J. (1890): Geología y Protohistoria ibéricas, Progreso, Madrid. 